\title{
Diversity and distribution of cold-seep fauna associated with different geological and environmental settings at mud volcanoes and pockmarks of the Nile Deep-Sea Fan
}

\author{
Bénédicte Ritt ${ }^{a,{ }^{*}}$, Catherine Pierre ${ }^{b}$, Olivier Gauthier ${ }^{a, c, d}$, Frank Wenzhöfer $^{\mathrm{e}, \mathrm{f}}$, Antje Boetius ${ }^{\mathrm{e}, \mathrm{f}}$ and \\ Jozée Sarrazin ${ }^{a, *}$
}

\begin{abstract}
alfremer, Centre de Brest, Département Etude des Ecosystèmes Profonds/Laboratoire Environnement Profond, BP 70, 29280 Plouzané, France

bLOCEAN, UMR 7159, Université Pierre et Marie Curie, 75005 Paris, France

'LEMAR, UMR 6539, Universiteé de Bretagne Occidentale, Place N. Copernic, 29200 Plouzaneé, France

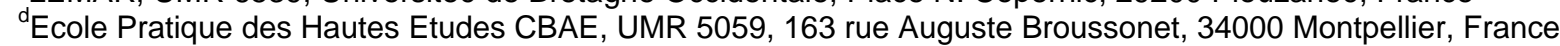

${ }^{\mathrm{e}} \mathrm{MPI}$, Habitat Group, Celsiusstrasse 1, 28359 Bremen, Germany

${ }^{\mathrm{f}}$ AWI, HGF MPG Research Group on Deep Sea Ecology and Technology, 27515 Bremerhaven, Germany
\end{abstract}

*: Corresponding authors : Bénédicte Ritt, email address : benedicte.ritt@ifremer.fr ; benedicte.ritt@temple.edu Jozée Sarrazin, Tel.: +33 2982243 29, Fax: +33 2982247 57, email address : jozee.sarrazin@ifremer.fr

\begin{abstract}
:
The Nile Deep-Sea Fan (NDSF) is located on the passive continental margin off Egypt and is characterized by the occurrence of active fluid seepage such as brine lakes, pockmarks and mud volcanoes. This study characterizes the structure of faunal assemblages of such active seepage systems of the NDSF. Benthic communities associated with reduced, sulphidic microhabitats such as sediments and carbonate crusts were sampled by remotely operated vehicles during two cruises in 2006 (BIONIL) and 2007 (MEDECO). Environmental conditions and biological factors including familylevel faunal composition, density and diversity were measured at local and regional scales. Significant differences were detected at different spatial scales: (1) the fauna of reduced habitats differed substantially in activity, diversity and biomass from the non-seep environment at similar water depth, (2) cold seep microhabitats showed differences in community structure and composition related to substratum type as well as to the intensity and location of fluid emissions.
\end{abstract}


Keywords: Nile Deep-Sea Fan; cold seeps; benthic macrofauna; alpha diversity; environmental conditions; chemosynthetic ecosystem; beta diversity.

\section{Introduction}

Since their discovery on the Florida Escarpment in the Gulf of Mexico (Paull et al. 1984), cold seeps have been reported along convergent plate boundaries on active as well as passive continental margins, where over-pressure in the sediments controls the emission of fluids enriched in methane or other hydrocarbons to the seafloor and hydrosphere (Milkov 2000; Dimitrov 2002). Depending on their geophysical settings, these cold seeps are associated with distinct geological features such as gas hydrates, pockmarks, brine lakes and mud volcanoes (MVs) (Milkov 2000; Hovland et al. 2002; Judd and Hovland 2007; Foucher et al. 2009). To date, hundreds of seep sites supporting chemosynthesis-based communities have been encountered throughout the world's oceans (Sibuet and Olu 1998; Levin 2005; Campbell 2006; Baker et al. 2010).

The Eastern Mediterranean Sea is one of the world's MV and pockmark hotspots (Kopf 2002; Foucher et al. 2009). Most of the MVs are associated with the active Mediterranean Ridge that stretches over more than $1500 \mathrm{~km}$ (Cita et al. 1981) and the thickly sedimented Nile Deep-Sea Fan (NDSF) along the Mesozoic-rifted continental margin of northern Egypt (Bellaiche et al. 2001; Mascle et al. 2001; Loncke et al. 2004; Mascle et al. 2006). The present study focuses on sites of the NDSF that have been explored since 2003 in the frame of the European Science Foundation (ESF) MEDIFLUX program (2003-2007) and the European $6^{\text {th }}$ Framework Program project HERMES (2005-2009).

The NDSF is divided into four morpho-structural provinces (Figure 1a): (1) the Levantine province, a domain of salt-related folding; (2) the Eastern province, a domain of intense salt-related tectonics; (3) the Central province with pockmark fields and gas chimneys, distinguished by active sedimentary instability and fluid-related processes; and (4) the Western province with mud cones, characterized by active turbiditic processes, salt tectonics and fluid venting (Mascle et al. 2006; Huguen et al. 2009). The accumulation of organic-rich sediments, probably since the early 
Cenozoic, led to the formation of hydrocarbons in deep reservoirs that were partially sealed by the deposition of thick evaporites during the Messinian (Hsu et al. 1977). A mixture of hydrocarbons, water and mud is expelled through faults that may extrude salt deposits, which reach the seafloor (Loncke et al. 2004). Fluid seepage is recorded in geological features such as mud cones, caldera-like depressions, gas chimneys, brine pools and pockmarks (Gontharet et al. 2007; Bayon et al. 2009a). Chemosynthesis-based communities have been observed in association with these different features (Huguen et al. 2005; Zitter et al. 2005; Dupré et al. 2007).
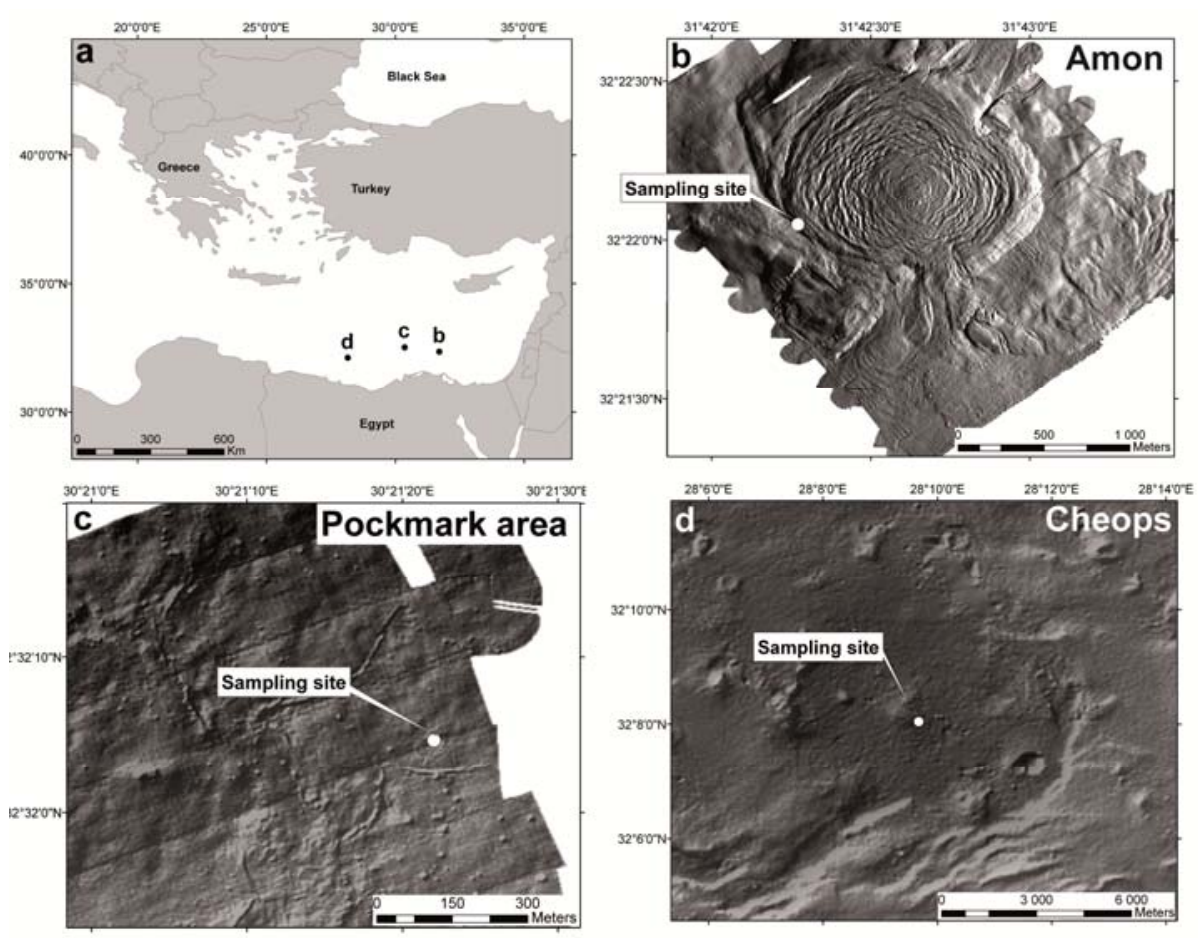

Fig. 1 (a) General map of the Eastern Mediterranean Sea with the localisation of the sampling sites in the three morpho-structural provinces: (b) the Amon mud volcano (MV) located in the Eastern province; (c) the Pockmark area located in the Central province and, (d) the Cheops MV in the Western province. Sampling sites are indicated on each MVs

Faunal assemblages associated with Mediterranean cold seeps from the NDSF are still relatively unknown. Only those from a few sites along the Mediterranean Ridge have been described, and symbiont-bearing species such as the siboglinid polychaete Lamellibrachia anaximandri, the lucinid Lucinoma kazani and the mytilid Idas modiolaefomis were identified (Salas and Woodside 2002; Olu-Le Roy et al. 2004; Werne et al. 2004; Duperron et al. 2008; Southward et al. in press). The distribution of fauna on the Amsterdam MV has been hypothesized to be linked to the 
amount of methane escaping from the mud flows, which decreases from the summit to the periphery (Olu-Le Roy et al. 2004). Likewise, biological zonation has also been observed on the Barbados prism (Olu et al. 1997) and the Håkon Mosby MV (Niemann et al. 2006; Jerosch et al. 2007). In both cases, the summit of the MV was covered by fresh gassy mud flows and devoid of visible epifauna. Communities dominated by sulphide oxidizing bacterial mats were observed close to the summit, followed by symbiont-bearing fauna and heterotrophic fauna towards the periphery (Olu et al. 1997; Zitter et al. 2003; Niemann et al. 2006; Jerosch et al. 2007). Fresh mud flows are often characterized by very high rates of upward flux of reduced sulphidic fluids, excluding animals (de Beer et al. 2006). Older mud flows, located at the periphery, transport lower concentrations of methane and sustain sulphide production, fueling chemosynthetic populations of siboglinid tubeworms or bivalves like Acharax. The latter migrate to deeper sediment layers to reach for reduced chemical compounds. This environment also constitutes a favorable habitat for heterotrophic fauna, which develop in response to a local increase in microbial production (Levin and Mendoza 2007).

The present study was the first opportunity to characterize the structure of the faunal assemblages in the NDSF seeps on two types of geological features: MVs and pockmarks. Prior to 2006, no ecological study had been performed on NDSF seep sites, with the exception of a few observations and samples taken during the NAUTINIL cruise in 2003 (Dupré et al. 2007; Bayon et al. 2009b; Huguen et al. 2009). The macro- and meiofaunal benthic communities associated with different microhabitats found in three provinces of the NDSF were sampled by remotely operated vehicles (ROVs) during two cruises: BIONIL in 2006 and MEDECO in 2007. The microhabitats were characterized with regard to their environmental conditions and faunal communities, mostly to family level. We then compared faunal composition, density and diversity at local and regional scales to test the hypotheses that 1) reduced habitats support higher biomasses but lower diversity of meio- and macrofauna compared to surrounding oxygenated habitats, 2) carbonate crusts and reduced sediments bear different faunal assemblages, 3) faunal composition is related to microhabitat type rather than to the larger geological setting, 4) beta diversity between the different microhabitats is related to differences in fluid flow and substratum type. 
2. Materials and methods

Faunal sampling and habitat characterizations were done during BIONIL M70/2b aboard the German R/V Meteor with the ROV Quest4000 (MARUM, University Bremen) in November 2006 and during leg 2 of MEDECO aboard the French R/V Pourquoi Pas? with the ROV Victor6000 (Ifremer) in November 2007.

\subsection{Study sites}

The cold seep sites from three of the four provinces of the NDSF were investigated: 1) the Amon MV in the Eastern province; 2) a carbonate cemented area close to a pockmark field associated with large debris-flows in the Central province; and 3) the Cheops MV in the Western province hosting large brine pools (Figure 1). A single reference sample located $15 \mathrm{~km}$ away from the centre of the Amon MV and outside the influence of fluid emissions, was sampled as a reference (hereafter marked "Ref") for oxygenated deep-sea sediments not associated with fluid flow.

\subsubsection{The Western province - the Amon MV} The Amon MV $\left(32^{\circ} 22^{\prime} 05^{\prime \prime} \mathrm{N}-31^{\circ} 42^{\prime} 27^{\prime \prime} \mathrm{E}\right.$, Figure $\left.1 \mathrm{~b}\right)$ is circular, approximately $3 \mathrm{~km}$ in diameter, and $90 \mathrm{~m}$ high. It lies close to the limit of the Messinian platform, at 1150 $\mathrm{m}$ water depth. The summit is covered with mud blocks and clasts and shows a disturbed, chaotically structured surface suggesting recent impacts of mud extrusion and gas expansion. Temperatures at the centre reach $45^{\circ} \mathrm{C}$ at $10 \mathrm{~m}$ below the seafloor, confirming high upward fluid flow at this MV (Dupré et al. 2007; Dupré et al. 2008). The periphery of the Amon MV is characterized by highly bioturbated hemipelagic sediments. At its south-western rise, a lateral flow of reduced muds was identified ('sulphur-band') surrounded by carbonate crusts that were both sampled in 2006 during BIONIL. The carbonate crusts were rather thick, we could not observe blackish muds or siboglinid colonies associated with them.

\subsubsection{The Central province - the Pockmark area}

The Central province hosts large carbonate-cemented areas associated with reduced debris-flows, and numerous small pockmarks located between 1700 and $2100 \mathrm{~m}$ depth (Figure 1c). The pockmarks form circular depressions of a few meters in diameter and about $1 \mathrm{~m}$ deep, and are associated with the presence of authigenic 
carbonate crusts and reduced sediments (Loncke et al. 2004). During BIONIL, benthic communities were sampled from one reduced blackish sediments site at midslope (site $2 \mathrm{~A}, 32^{\circ} 32^{\prime} 00^{\prime \prime} \mathrm{N}-30^{\circ} 21^{\prime} 10^{\prime \prime} \mathrm{E}, 1700 \mathrm{~m}$ ) as well as from their surrounding carbonate cements. These were directly associated with blackish muds, and living siboglinid colonies were observed between the cracks of the flat, thin carbonates.

\subsubsection{The Eastern province - the Cheops MV}

The Cheops MV is located within the Menes caldera at $3000 \mathrm{~m}$ depth $\left(32^{\circ} 08^{\prime} 05^{\prime \prime} \mathrm{N}-\right.$ $28^{\circ} 09^{\prime} 67^{\prime \prime} \mathrm{E}$, Figure 1d), above the Messinian platform. This caldera is a circular $50 \mathrm{~m}$ deep depression $8 \mathrm{~km}$ in diameter. As previously observed in 2003 during the NAUTINIL cruise, a mixture of brine and mud was flowing from Cheops during the sampling operations in 2007 (MEDECO). The mud is expelled from deep layers as indicated by high temperature anomalies (Huguen et al. 2009). This MV is also characterized by numerous brine pools, covered by bright white matter, identified as microbial sulphur deposits (Dupré et al. 2007; Omoregie et al. 2008). Brine pools constitute direct evidence of fluid emissions, and the migration of fluids enriched in salt induces high sediment instability that may influence faunal composition and distribution on this MV. Faunal sampling and environmental characterizations were carried out during MEDECO. Sparse carbonate crusts were observed but not sampled.

\subsection{Description of the microhabitats}

At all cold seep sites visited, ROV surveys indicated a mosaic of visually distinguishable microhabitats, characterized by the presence of visible fauna or microbial mats. Two types of reduced habitats were sampled: 1) reduced blackish sediments (Red) covered with whitish bacterial mats or small tubeworms at the surface (Figures 2a, c, e) and 2) carbonate crusts (CC) that were dark-colored at Amon, or "crumbly" and of whitish to light grey color at the Pockmark area Figures $2 b, d)$.

Chemical characterization of the microhabitats was performed above the reduced sediments of Cheops MV during MEDECO. Water samples were taken for chemical analyses using the PEPITO water sampler above the organisms as close as possible to the seafloor using the Victor6000 manipulator arm. PEPITO collects water in 200 
$\mathrm{ml}$ titanium bottles (Sarradin et al. 2009). Chemical measurements and sediment samples were taken during BIONIL as close as possible above the seafloor or in soft sediments with bottles $(750 \mathrm{ml})$ and push cores (inner diameter $7.5 \mathrm{~cm}$ ) at 2.5 to 50 $\mathrm{m}$ from the sampled microhabitats. Further sampling details are given in Table 1.
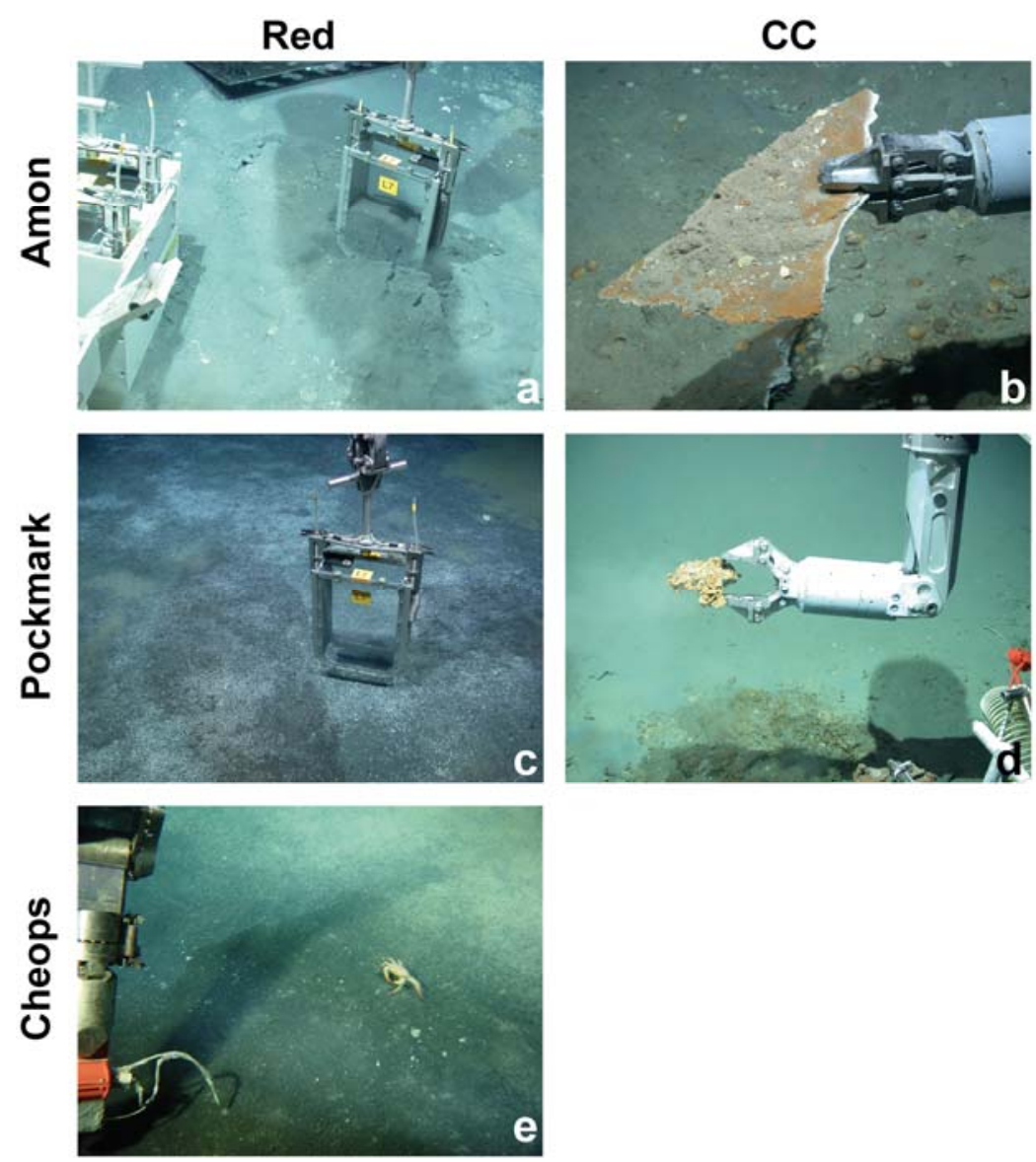

Fig. 2 Representative photographs of the microhabitats sampled in the three study sites. On the Amon MV: (a) reduced sediments and (b) carbonate crusts; in the Pockmark area: (c) reduced sediments and (d) carbonate crusts; on the Cheops MV: (e) reduced sediments. Red: reduced sediments CC: carbonate crusts. All microhabitats were sampled during the BIONIL (2006) and MEDECO (2007) cruises. Photos a, b, c, d: MARUM, University Bremen, QUEST4000 and photo e: Ifremer, Victor6000

Epi- and endofauna were sampled with blade corers on a surface of $200 \mathrm{~cm}^{2}$ (Menot et al. 2010) on all soft sediment sites (Figures 2a, c, d, g) and pieces of carbonate crusts were sampled using the claw of the ROV Victor6000 (Figures 2b, e). A reference site $15 \mathrm{~km}$ away from the active centre of Amon has been sampled with a single multicorer on which 3 tubes of a surface of $74 \mathrm{~cm}^{2}$ were sampled (pseudoreplicates). The number of samples for each microhabitat is reported in Table 1. 
Quantitative sampling of the crusts was difficult because they had to be broken off in pieces with the submersible manipulator. No crusts were obtained from Cheops.

\subsection{Physico-chemical analyses}

The $200 \mathrm{ml}$ water samples were used to determine methane concentrations using the technique of headspace sampling gas chromatography with a thermal-conductivity detector (TCD) and a flame-ionisation detector (error of $4 \%$; see method in Sarradin and Caprais 1996).

Sediments from push corers were split horizontally at $1 \mathrm{~cm}$ intervals on board and porewater was extracted by centrifugation of the different sediment layers. After filtration and dilution, sulphate and chloride concentrations were measured by nonsuppressed anion exchange chromatography (Water IC-Pak anion exchange column, waters 430 conductivity detector). Total dissolved sulphide concentrations were determined with the diamine complexation method by colorimetric method (Cline 1969). Intact cores, along with supernatant water, were used for $\mathrm{pH}$, oxygen and total dissolved sulphide concentration measurements. Small-scale porewater concentration profiles for $\mathrm{O}_{2}, \mathrm{H}_{2} \mathrm{~S}$, and $\mathrm{pH}$ were performed on push core samples from soft sediments using microelectrodes as described in de Beer et al. (2006). Microelectrodes with a tip diameter of ca. $20 \mu \mathrm{m}$ were lowered into the sediment with a step resolution of $200 \mu \mathrm{m}$ to monitor the concentration profiles within the upper sediment layer. Total oxygen consumption was measured in situ using a ROVoperated benthic chamber module (Treude et al. 2009). The chamber encloses an area of ca. $285 \mathrm{~cm}^{2}$ together with approximately $10-15 \mathrm{~cm}$ of overlying bottom water. The change in $\mathrm{O}_{2}$ concentration over time in the enclosed water volume was continuously monitored by two Clark-type mini-electrodes mounted in the chamber lid. This measurement integrates all relevant transport and consumption processes (diffusion, advection and fauna mediated transport as well as fauna respiration).

\subsection{Faunal sorting and identification}

The faunal samples were processed as described in Ritt et al. (2010). Sediments from blade corers were photographed and split horizontally $(0-1,1-3,3-5,5-10,>10$ $\mathrm{cm}$ ) immediately after recovery. The range of the last slice depended on core lengths that varied from 10 to $20 \mathrm{~cm}$ (Table1). Core slices were passed through a sieve 
column ( $2 \mathrm{~mm}, 1 \mathrm{~mm}, 500 \mu \mathrm{m}, 250 \mu \mathrm{m})$ and the retained sediment was preserved in $10 \%$ buffered formalin. In the laboratory, all sediments up to $10 \mathrm{~cm}$ below the seafloor were rinsed and invertebrates were sorted under a dissecting microscope and identified to the lowest taxonomic level possible (here mostly family level). In this study, we considered macrofauna sensu stricto ( $>250 \mu \mathrm{m}$, Hessler and Jumars 1974), and any meiofaunal taxa such as Nematoda, Copepoda, Ostracoda and Acarina were analysed separately. As a consequence, meiofaunal samples contain only the largest fraction retained by a $250 \mu \mathrm{m}$ mesh, and do not include the $32 \mu \mathrm{m}$ or $62 \mu \mathrm{m}$ size limit usual for meiofauna (Hessler and Jumars 1974; Thistle 2003; Van Gaever et al. 2006).

The CC samples were preserved individually in $10 \%$ buffered formalin on board after recovery. In the laboratory, the carbonates crusts were treated individually by retrieving the organisms embedded or attached on them without breaking the carbonate crusts. Then they were washed over a $250 \mu \mathrm{m}$ mesh and the organisms retained were processed as those on the soft sediments. The surface of the sampled carbonate crusts were estimated using the IPLab Spectrum ${ }^{\circledR}$ image analysis software. Quantitative 2-D surface analyses were performed on video images of the upper face of the crusts, and we did it thrice to reduce error resulting from on-screen tracing (Sarrazin and Juniper 1999). Total surface area was used to calculate arearelated indicators, such as density and biomass by counting organisms at both faces and in the holes but divided the total of individuals only by the surface area. However, because it does not take topography into account, this method may underestimate total surface area and in turn overestimate density and biomass. The crusts from the Pockmark area had a more complex topography with numerous holes in comparison with the flat carbonates from Amon, hence, the two-side method may have added to the uncertainty with areal estimates in this case.

\subsection{Vertical distributions}

Vertical distributions within each reduced sediment microhabitat and the reference site were studied in the depth layers 0-1, 1-3, 3-5 and 5-10. Densities were calculated by summing up the sediment layers up to $10 \mathrm{~cm}$ below the seafloor. This was repeated for relative abundance and biomass. Biomass was assessed by measuring the mean preserved wet weight (pww) for each microhabitat. To do so, individuals of 
all major macrofaunal taxa (bivalves, polychaetes, gastropods and crustaceans) were pooled, pat-dried on absorbent paper and weighed on a microbalance with an error of $0.1 \mathrm{mg}$.

\subsection{Diversity measurements}

Within-microhabitat ( $\alpha$-diversity) and between-microhabitat ( $\beta$-diversity) diversity (Whittaker 1960; Gray 2000) were estimated for all microhabitats.

\subsubsection{Alpha-diversity}

The $\alpha$-diversity analyses were performed at the family level, which was reached for most of the taxa except Zoantharia, Scyphozoa, Terebellida, Isopoda, Leptostraca, Nematoda and Acarina. Undetermined families, individuals and larvae were removed from the analysis because of the probability that they belong to a family already listed. This may have resulted in an underestimation of the taxonomic richness. Sample-based rarefaction curves (sensu Gotelli and Colwell 2001) were calculated on macrofaunal datasets for each of the three study sites (Sanders 1968). Individualbased rarefaction curves were also computed on macrofaunal datasets for each microhabitat type, regardless of the province of origin. These curves plot expected taxonomic richness against sampling effort and allow comparisons impossible with observed richness (S). All rarefaction curves use the expected number of individuals as the X-axis (Sanders 1968, corrected and modified by Hurlbert 1971; Gotelli and Colwell 2001; Gauthier et al. 2010). Observed within-microhabitat taxonomic diversity was evaluated using common diversity indices as well as more robust intrinsicdiversity-based ordering methods (Liu et al. 2007; Gauthier et al. 2010). Commonly used to define the $\alpha$ diversity, the taxonomic richness $(S)$, the number of taxonomic groups observed in each microhabitat, the Shannon's entropy ( $H_{e}^{\prime}$; Shannon 1948) and the Gini-Simpson diversity index ( $D_{G S}$; Gini 1912; Simpson 1949) were calculated. They are presented along with their numbers equivalents, allowing straightforward comparisons between communities (Hill 1973; Patil and Taillie 1982; Jost 2006; Jost 2007). Community evenness was also determined using Pielou's index of evenness ( $J$; ; Pielou 1969). 
The right tail-sum method (RTS) is a diversity ordering method, which is more robust and stringent than other methods and allows graphical comparisons of communities (Patil and Taillie 1982; Tothmérész 1998; Liu et al. 2007). Communities are ordered in decreasing diversity from the top most curves to the lowest ones. No clear conclusions can be drawn when curves intersect (Liu et al. 2007).

\subsubsection{Beta-diversity}

Despite the modest number of samples, multivariate analyses were conducted to better illustrate the similarities and differences among faunal samples. The lowest available taxonomic level was used. Principal component analysis (PCA) and Ward's hierarchical clustering were used to indirectly evaluate the influence of habitat conditions on community structure variation within and between the different microhabitats and sites, but excluding the undetermined taxa as previously explained for the alpha-diversity. A Procrustean randomization test (Jackson 1995) was performed to compare the PCA results of the macrofaunal and meiofaunal datasets. Abundance data were first Hellinger-transformed to conserve Hellinger, rather than Euclidian, distances in PCA (Legendre and Gallagher 2001). Hellinger distances were also used for Ward's hierarchical clustering. This distance gives low weight to rare taxa in the analyses. In marine ecology in general, and even more so in the deep-sea, rare species are not well sampled, and their sporadic appearance in samples is mosly attributable to sampling error. In the PCA, the equilibrium contribution circle was computed to identify the taxa having the most impact on the position of the samples in the ordination (Legendre and Legendre 1998).

The Jaccard's similarity coefficient $\left(s_{\text {jacc }}\right)$ was used to quantify similarity in terms of shared taxa among replicates within each microhabitat (Jaccard 1901); giving equal weight to all taxa. Mean Jaccard similarity was computed to evaluate withinmicrohabitat variation.

All analyses were performed in the R environment ( $R$, Development Core Team, 2009). Rarefaction curves, diversity indices and diversity profiles were computed both with the Biodiversity R package (Kindt and Coe 2005) and functions in Gauthier et al. (2010). Multivariate analysis was carried out using the vegan package (Oksanen et al. 2008). 


\section{Results}

\subsection{Physico-chemical characterization of microhabitats}

The length of the cores varied from 10 to $20 \mathrm{~cm}$ depending on the nature of the substratum (Table 1). All samples came from surface cold seep habitats at in situ bottom water temperature of $13.5^{\circ} \mathrm{C}$, as at the reference site. The Red cores from the Pockmark area contained black sediments with a strong hydrogen sulphide odor. At Amon, a horizon of $8-10 \mathrm{~cm}$ of black sediments overlaid grayish to beige hemipelagic sediments. On Cheops, a black layer of only 1-2 cm was found on top of beige hemipelagic sediments. The cores of the reference site contained only beige sediments.

\subsection{Chemical characterization at a larger scale around microhabitats}

\subsubsection{Bottom water measurements}

Overall, the $\mathrm{pH}$ was slightly lower in reduced sediments than at the reference site (Table 2). According to microprofiler measurements, $\mathrm{pH}$ value reached 7.9 at the interface of reduced sediments on Amon while in the Pockmark area, it was around 8.1 (Table 2).

Oxygen bottom water concentrations were similar at all sites, including the reference site (200-230 $\left.\mathrm{mmol}^{-1}\right)$ with the exception of the reduced sediments at Amon, where a temporary depletion was observed, reaching values below $200 \mu \mathrm{mol} \mathrm{I}^{-1}$. No free sulphide was detected in the bottom waters at any of the sites, but sulphide was found within the porewaters at two reduced sediment sites (Table 2). Low concentrations of methane were measured in the bottom waters of Cheops and the Pockmark area while they ranged between 3.6 and $9.3 \mu \mathrm{mol} \mathrm{I}^{-1}$ in the overlying water of Cheops samples (Table 2).

Sulphate values of $31 \mathrm{mmol} \mathrm{I}^{-1}$ and chloride values of $529 \mathrm{mmol} \mathrm{I}^{-1}$ were measured above and throughout the core from the reference site. Sulphate and chloride measurements above the reduced sediments on Amon showed values varying from 30 to $40 \mathrm{mmol} \mathrm{l}^{-1}$ and 404 to $580 \mathrm{mmol} \mathrm{I}^{-1}$ respectively (Table 2). Here, spatial heterogeneity between samples was high, despite the proximity of the cores (few $\mathrm{dm}$, e.g. PC 46 and PC 47). In microbial mats from the Pockmark area, sulphate 
concentrations varied from 29 to $30 \mathrm{mmol}^{-1}$ while chloride values were high, ranging from 606 to $630 \mathrm{mmol}^{-1}$ (Table 2).

\subsubsection{Porewaters, oxygen consumption and sulfate reduction rates in sediments} Oxygen penetration depth measured by microsensors was $>4 \mathrm{~cm}$ at the reference site (Table 2). The porewater samples from the reference site did not contain sulphide or methane. Accordingly, sulphate reduction rate at the reference site was not measurable, and oxygen consumption was $<1 \mathrm{mmol} \mathrm{m}^{-2} \mathrm{~d}^{-1}$ (Table 2).

In contrast, oxygen microsensor profiles in reduced sediments of Amon, Cheops and the Pockmark area showed complete oxygen consumption within the first 1-2 millimeters of seafloor (Figures 3a, b). Total dissolved sulphide profiles in reduced sediments of Amon showed a maximum concentration of $2.5 \mathrm{mmol} \mathrm{I}^{-1}$ at $12 \mathrm{~cm}$ depth and were $<0.8 \mathrm{mmol} \mathrm{I}^{-1}$ in the top $5 \mathrm{~cm}$ (Table 2, Figure 3c). The profile suggested that sulphide was oxidized completely within the first millimeters of sediment. In the Pockmark area, sulphide concentrations at $12.5 \mathrm{~cm}$ depth reached $25 \mathrm{mmol} \mathrm{l^{-1 }}$ (Figure 3d), but sulphide was also completely consumed within the surface sediments (Table 2). No porewater data were available for Cheops due to limitation in dive time.

At the reference site off Amon, sulphate and chloride concentrations were homogeneous along the whole length of the core with a mean of $32 \pm 2.4 \mathrm{mmol} \mathrm{I}^{-1}$ for sulphate and $530 \pm 49.5 \mathrm{mmol} \mathrm{I}^{-1}$ for chloride (Figure 4a). On Amon reduced sediments, sulphate and chloride profiles were homogeneous along the length of the core reaching values similar to the reference sample with the exception of a high sulphate concentration at the top of the core (Figure 4b). In the Pockmark area, the consumption of sulphate was visible throughout the $16 \mathrm{~cm}$ of the core length, whereas lower variation was observed in chloride (Figure 4c). 
Amon
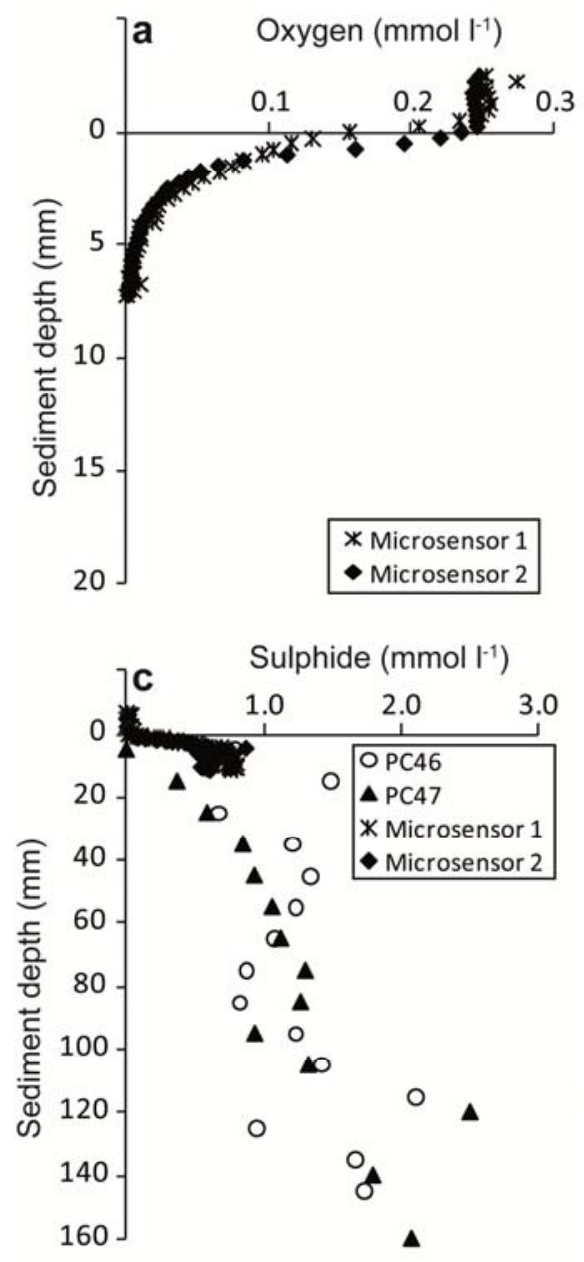

Pockmark
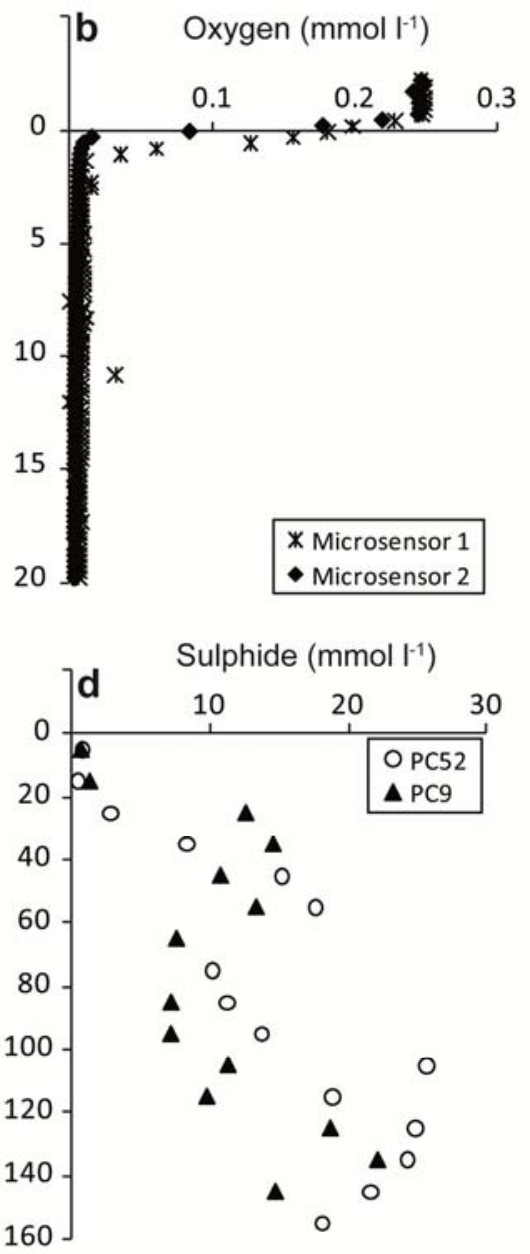

Fig. $3(a, b)$ Dissolved oxygen and (c, d) sulphide profiles measured by microsensors and in pore water extracted from push corers $(P C)$ taken in reduced sediments on the $(a, c)$ Amon MV and in (b, d) bacterial mats covering reduced sediments in the Pockmark area. The measurements were performed during the BIONIL cruise (2006)

398 Integrated sulphate reduction rates were negligible at the reference site, and low at the reduced sediment of Amon. Intermediate rates were measured for Cheops and high rates associated with the Pockmark area (Table 2). Likewise, total benthic oxygen fluxes were very low at the reference site, and 1-2 orders of magnitude higher at all reduced sediment sites, with the highest rates associated with the black sediments of the Pockmark area (Table 2). 

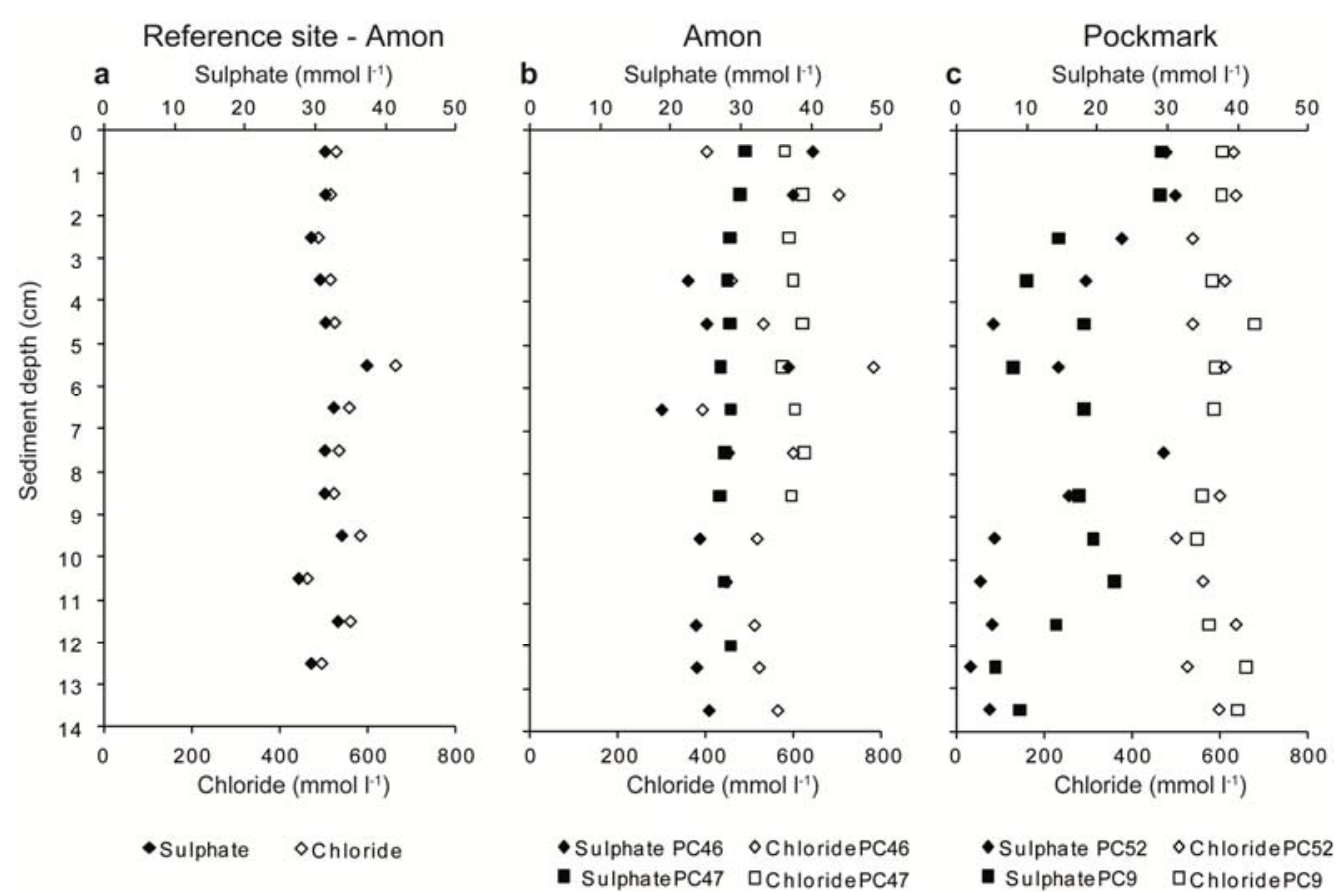

Fig. 4 Sulphate and chloride profiles measured in porewater extracted from sediment cores sampled (a) at the reference site off Amon MV, (b) in reduced sediments on the Amon MV and, (c) in bacterial mats covering reduced sediments in the Pockmark area. The measurements were performed during the BIONIL cruise (2006)

3.3. Macro- and meiofaunal community description

3.3.1. Composition, abundance, density and $\alpha$-diversity patterns

Mean macrofaunal densities varied from 650 to 2,100 individuals $\mathrm{m}^{-2}$ at Amon (Table 3), $1,950-3,500$ individuals $\mathrm{m}^{-2}$ in the Pockmark area (Table 43) and from 3,200 to 5,250 individuals $\mathrm{m}^{-2}$ at Cheops (Table 4). This represents approximately $3.5 \%, 55 \%$, and $78 \%$ of the total fauna sampled at each site (Tables 5,6$)$. In comparison, the fully oxic reference site had from 541 to 1,081 macrofaunal individuals $\mathrm{m}^{-2}$ (Table 3 ), which represented $67 \%$ of the total fauna. On the carbonate crust microhabitat (CC), densities varied from 1,852 to 7,353 individuals $\mathrm{m}^{-2}$ at Amon (Table 3) and from 1,852 to 7,353 individuals $\mathrm{m}^{-2}$ in the Pockmark area (Table 4) representing respectively $100 \%$ (except CC2 where it only represent 20\%) and $63 \%$ of the fauna sampled (Tables 3, 4).

Despite the large sieve mesh size used (250 $\mu \mathrm{m})$, many specimens corresponding to meiofaunal groups (copepods, ostracods, nematodes, mites) were found in our samples (Tables 5, 6). Mean densities of meiofauna $>250 \mu \mathrm{m}$ varied from 31,800 to 
75,550 individuals $\mathrm{m}^{-2}$ at Amon (Table 5), 1,450 to 3,950 individuals $\mathrm{m}^{-2}$ in the Pockmark area (Table 6) and reached 600 to 2,850 individuals $\mathrm{m}^{-2}$ at Cheops (Table 6). At Amon, meiofaunal mean density was higher in reduced sediments compared to carbonate crusts (Table 5). Overall, nematodes dominated the meiofauna $>250 \mu \mathrm{m}$ samples, varying from 95 to $100 \%$ of total abundances on the reduced sediments from the Amon and Cheops (Tables 5, 6). However, in the reduced sediments of the Pockmark area, nematodes represented only $36 \%$ of the meiofauna (Table 6). Here, harpacticoid copepods reached up to $37.5 \%$ of the meiofaunal abundance, followed by ostracods $(\sim 16 \%)$. Surprisingly, besides four nematodes, no meiofauna was sampled from the CC microhabitat of Amon, compared to a relatively high number of nematodes found at the $\mathrm{CC}$ of the Pockmark area (Tables 5, 6).

Relative faunal abundances varied between microhabitats and between replicate samples of the same microhabitat, especially on carbonate crusts. Overall, the steady increase of the individual-based rarefaction curves suggests that the sampling effort was not sufficient (Figure 5a). Only the curves of the reduced microhabitats of Cheops and the Pockmark area showed that we attained a relatively good estimation of their taxonomic richness. These curves also showed that the taxonomic richness between the different reduced sediment microhabitats was highest on Amon, followed by the Pockmark area and finally Cheops. The opposite trend was observed for the $\mathrm{CC}$ microhabitats, where the diversity was higher in the Pockmark area (Figure 5a). Since the ranking of the curves would probably remain the same with additional macrofaunal samples, we can conclude with confidence that the total family richness (S) on Amon was highest on reduced sediments, intermediate on the Reference site and lowest on $\mathrm{CC}$, while the $\mathrm{CC}$ microhabitat in the Pockmark area was richer than the reduced sediments (Figure 5a; Tables 7, 8).

In terms of evenness (Pielou's index J', Table 8), the reference sample harbored the most even distribution followed by $\mathrm{CC}$ from the Pockmark area and reduced sediments from Amon (also shown in Figure 5b). Finally, Red from Cheops was the poorest microhabitat sampled in the NDSF. It was amongst the least even of all microhabitats along with $\mathrm{CC}$ from Amon and Red from Pockmark (Tables 7, 8). At Amon, polychaetes were the dominant taxa in the reduced habitats and reference samples, constituting respectively $\sim 82 \%$ and $71 \%$ of total faunal abundance. A total 
of 8 polychaete families or orders (since the Terebellida were not identified at the family level) were represented in the reduced sediments (Tables 3,7 ). With $\sim 11.5 \%$ of the total macrofaunal abundance, bivalves were the second dominant taxon in the reduced sediments of Amon, whereas cnidarians ( $18 \%)$ ranked second in the reference sample. Gastropods and crustaceans were present in low abundance $(<6 \%)$ in reduced sediments while on the reference samples, low abundances were for the crustaceans and sipunculians. On CC from Amon, cnidarians represented $72 \%$ of the total abundance, distantly followed by polychaetes $(-17 \%$; Table 8$)$. Some gastropods and sipunculians were also present in low abundance $(<6 \%$; Table 3a). In the Pockmark area, reduced sediments were dominated by 8 polychaete taxa, reaching $\sim 84 \%$ of the total macrofaunal abundance, followed by bivalves and gastropods (Tables 4, 7). Contrary to Amon, the fauna from CC in the Pockmark area was more evenly distributed with gastropods and polychaetes representing respectively $\sim 51 \%$ and $40 \%$ of the total abundance (Table 4). Bivalves and crustaceans were also present, representing less than $8 \%$ of the total macrofaunal abundance (Table 4). The rarefaction curves and the Pielou's index confirm the higher evenness of the $\mathrm{CC}$ from the Pockmark area compared to $\mathrm{CC}$ from Amon (Figure 5a; Tables 7, 8), the highest evenness being observed on the reference site (Table 8). Finally, on Cheops, polychaetes largely dominated reduced sediments, with a mean of $96 \%$ of the faunal abundance, followed by low proportions of crustaceans and gastropods (Tables 4, 7).
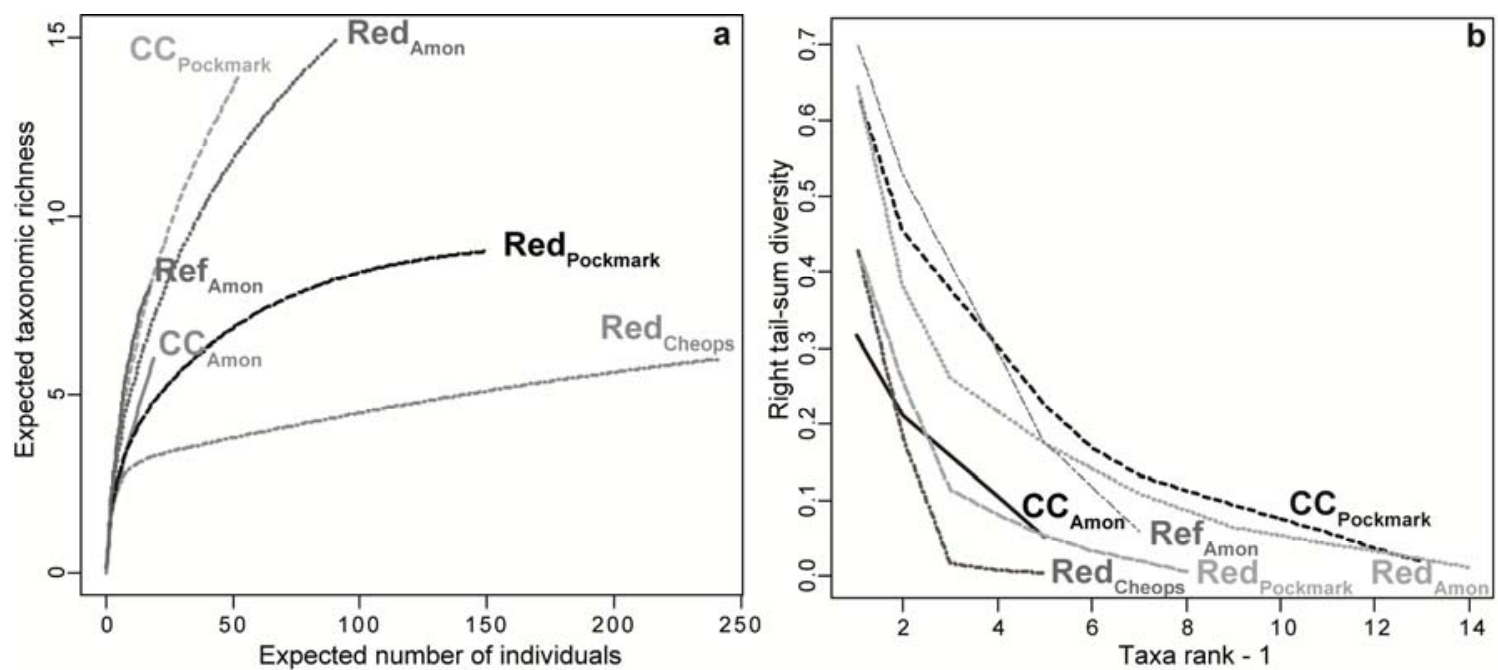

Fig. 5 (a) Rarefaction curves (b) and right tail-sum intrinsic diversity profiles for the pooled macrofaunal abundance data at the family level and at each microhabitat from the Amon MV (3 microhabitats including the reference sample), the Pockmark area (2 microhabitats) and the Cheops MV (1 microhabitat) 
The RTS performed with the same dataset is difficult to interpret due to the crossing of the curves (Figure 5b). Using this analysis, Amon reduced sediments were the richest and most even microhabitat among the three reduced sediments. In contrast, the $\mathrm{CC}$ from the Pockmark area was more diverse than that from Amon (Figure 5b).

Finally, we pooled the data obtained for the different microhabitats to determine the diversity of each site, including the reference samples from Amon. For Amon and the Pockmark area, the sample-based rarefaction curves did not level-off, suggesting that sampling was insufficient to accurately estimate taxonomic richness (Figure 6a). At Cheops, despite the low sample number $(n=3)$, the curve leveled-off, suggesting that its macrofaunal diversity was well described (Figure 6a). Our data indicate that diversity was higher at microhabitats sampled on Amon, followed by the Pockmark area, the reference samples from Amon and lastly, by Cheops (Figure 6a). Overall, the distribution of macrofauna was relatively even on Amon, since the most abundant taxon only reached $\sim 30 \%$ for both active and reference sites, whereas the most abundant taxon represented $\sim 45 \%$ and $\sim 55 \%$ on the Pockmark area and Cheops respectively (Figure 6b).
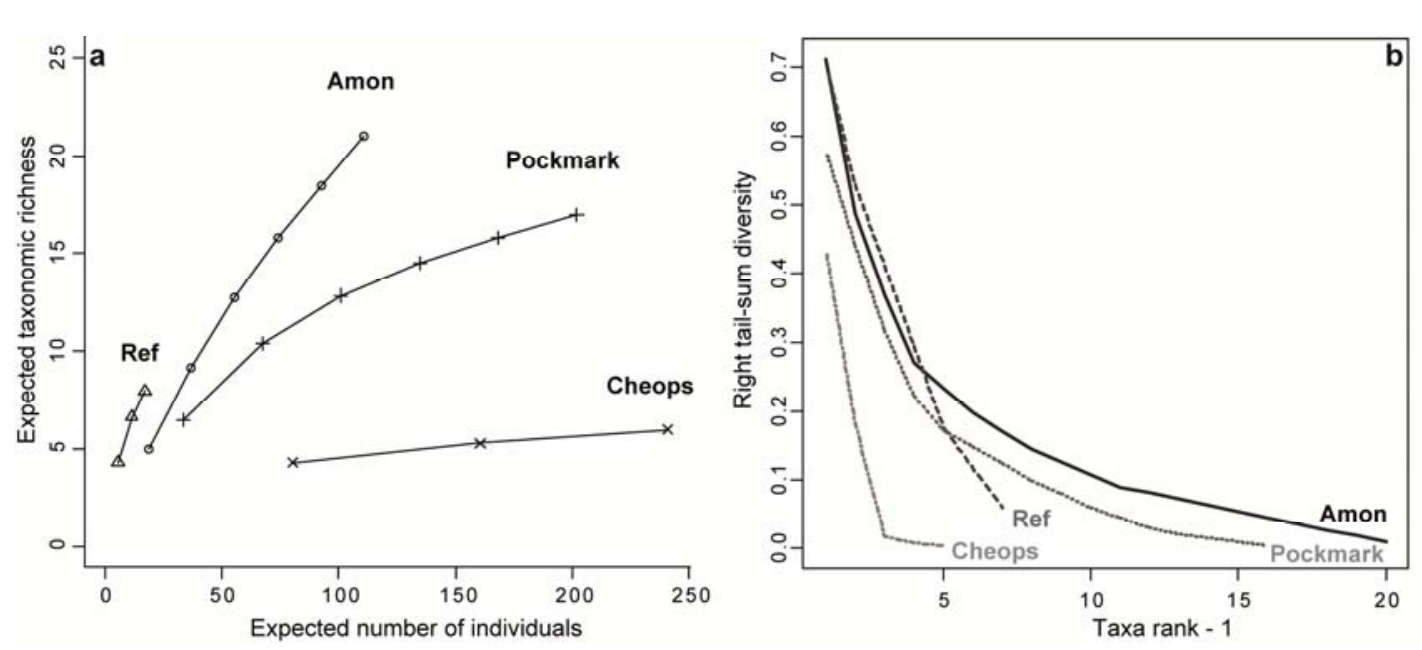

Fig. 6 (a) Rarefaction curves and (b) right tail-sum intrinsic diversity profiles for the pooled macrofaunal abundance data at the family level, according to the three study sites after pooling active microhabitats. Amon $M V, n=6$, Pockmark area $n=3$, and Cheops $M V, n=3$. The reference sample from Amon is reported separately, $n=3$ (Ref) 


\subsubsection{Symbiont-bearing fauna versus heterotrophic fauna}

The symbiont-bearing fauna (for types of symbioses see Olu-Le Roy et al. 2004) represented 17 to $36 \%$ of the total faunal abundance in the reduced sediments from Amon, while the $\mathrm{CC}$ and the reference sample did not harbour any (Tables 7, 8). The symbiont-bearing fauna was represented by Frenulata polychaetes as well as by four bivalve species (Lucinoma kazani, Idas modiolaeformis, Thyasira striata and Isorropodon perplex; Table 3). The Pockmark area had between 10 and 16\% of symbiont-bearing fauna both in the sediment and CC microhabitats, respectively (Tables $5,7,8$ ). This fauna was represented by two known bivalve species (L. kazani and $I$. perplexum) and one unknown Lucinidae in the sediments. Only one bivalve species was present in the CC microhabitat (I. modiolaeformis; Table 4). No symbiont-bearing fauna was sampled at Cheops (Tables 7,8$)$ or at the reference site.

\subsubsection{Vertical distributions within the sediments}

The distribution within the sediment layers down to $10 \mathrm{~cm}$ below the seafloor of the macrofaunal relative abundances differed between the three reduced sediment microhabitats (Figure 7a). At all reduced sediment sites, oxygen did not penetrate deeper than a few $\mathrm{mm}$, and sulfide concentration increased with sediment depth below $2 \mathrm{~cm}$ to $1-2 \mathrm{mmol} \mathrm{I}^{-1}$ at Amon and to $10-20 \mathrm{mmol} \mathrm{I}^{-1}$ in sediments of the Pockmark area. Hence, in the Pockmark area, the macrofauna was concentrated at the uppermost layer [0-1 cm] with about $85 \%$ of the total abundance (Figure 7a). However, some capitellid polychaetes and undetermined bivalves - that may be vesicomyids and lucinids - were found in the $[5-10 \mathrm{~cm}]$ layers. In the Cheops area, the macrofauna was almost evenly distributed between the $[0-1 \mathrm{~cm}]$ and $[1-3 \mathrm{~cm}]$ layers and only few spionid polychaetes were found in the $[5-10 \mathrm{~cm}]$ layer. The profile obtained for the reduced sediments of Amon was different, with a more homogeneous distribution within the $10 \mathrm{~cm}$ layer and a relatively high abundance at [5-10 cm] (Figure 7a) especially of frenulate, capitellid and dorvilleid polychaetes. At the reference site, most macrofauna was concentrated in almost equal proportions in the two first layers $[0-1 \mathrm{~cm}]$ and $[1-3 \mathrm{~cm}]$. There, the distribution showed a clear decrease with depth, as no organism was found at the [5-10 cm] layer (Figure 7a). The meiofauna $>250 \mu \mathrm{m}$ also decreased with depth at the reference site, with up to $60 \%$ of the total meiofaunal abundance found in the two first layers (Figure $7 \mathrm{~b}$ ). The 
same trend was observed in reduced sediments from Amon with this time almost $60 \%$ concentrated in the first layer. This pattern was different at the Pockmark area, where the meiofaunal abundance was highest in the [3-5 cm] layer followed by the [1$3 \mathrm{~cm}$ ] and [5-10 cm] layers (Figure 7b). However, the few organisms found in the [5$10 \mathrm{~cm}$ ] layer consisted of nematodes at Amon, and of harpacticoid copepods at the Pockmark area.
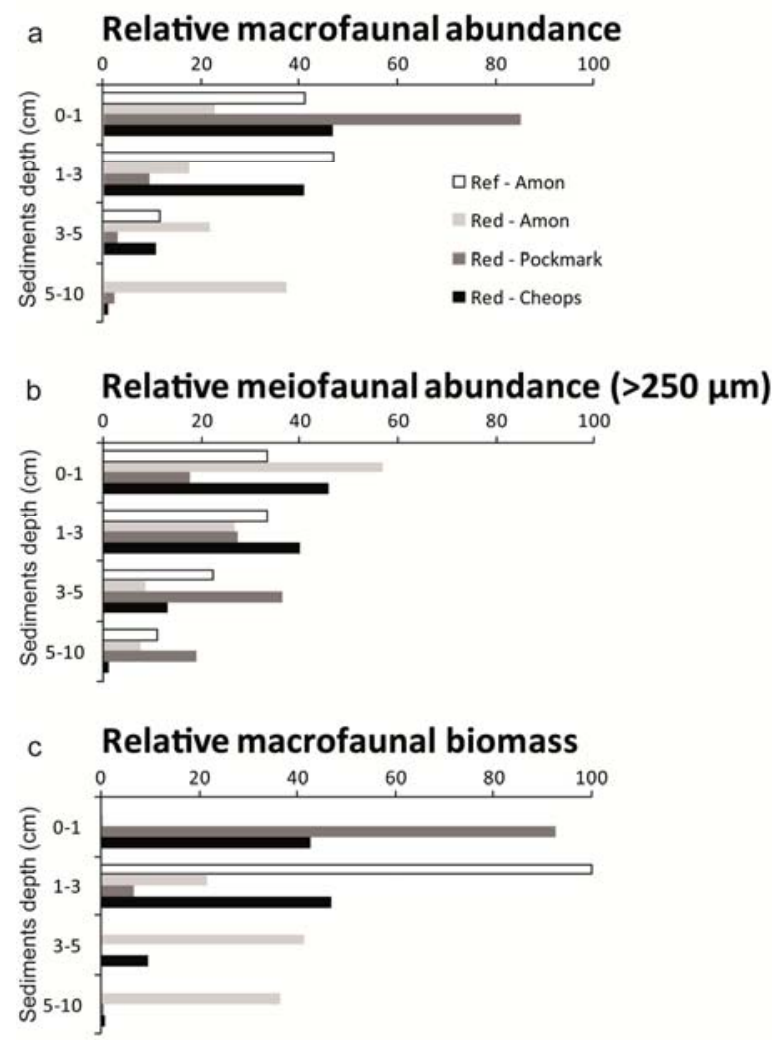

Fig. 7 Vertical distribution of (a) macrofaunal and (b) meiofaunal $(>250 \mu \mathrm{m})$ relative abundances and (c) macrofaunal relative biomass with depth after summing the three replicates $(n=3)$ for each sediment layer of the reduced sediment microhabitats from Amon MV, Pockmark area and Cheops MV. The reference site from Amon is also included

In general, all soft sediments showed a low macrofaunal biomass, except the reduced sediments of Amon where the mean biomass reached $0.12 \pm 0.1 \mathrm{~kg} \mathrm{pww} \mathrm{m}^{-2}$ (Table 7). Here, the vertical distribution showed an increase with depth from 1 to 10 $\mathrm{cm}$ with about $40 \%$ of the total macrofaunal biomass remaining in the $[5-10 \mathrm{~cm}]$ layer (Figure 7c) due to the presence of few lucinid and thyasirid bivalves. In the reduced sediments of the Pockmark area, most of the macrofaunal biomass (93\%) was observed within the top layer [0-1 cm] and mainly consisted of dorvilleid polychaetes.

Reduced sediments at Cheops hosted a similar biomass in the top two layers [0-1] 
and [1-3 cm], with 43 and $47 \%$ of the total biomass respectively mainly represented by hesionid, spionid, terebellid polychates and Leptostraca crustaceans. Next, a sharp decrease was observed with depth (Figure 7c). At the reference site, mean biomass was very low (Table 8), and integrally located within the [1-3 cm] layer (Figure 7c) due to the presence of one sipunculian and few spionid polychaetes.

\subsubsection{Beta diversity patterns}

The first two components of the principal component analysis (PCA) on macrofaunal data accounted for $41.7 \%$ of the variance in macrofaunal distribution (Figure $8 \mathrm{a}$ ). Three clusters appear in reduced space: the carbonate crust samples; the reduced sediment samples except those from Cheops; and the Amon reference site and Cheops reduced sediments samples. Thus the variability between microhabitats was higher than that within the microhabitats, but lower than that among the geostructures (Figure 8). Polychaete taxa (Spionidae, Terebellida, Dorvilleidae, Capitellidae) and gastropods (Orbitestellidae) had the greatest impact on the variation in community structure. Focusing on these taxa, they appeared to be indicative of different groups, representing different types of microhabitats rather than different sampling locations. In the first group, Spionidae and Terebellida highly contributed to the positioning of the reduced sediments from Cheops and reference samples from Amon. In the second group, Orbitestellidae highly contributed to the positioning of both carbonate crust microhabitats (Pockmark and Amon). Finally Capitellidae and Dorvilleidae presented high contributions in reduced sediments from Amon and Pockmark area (Figure 8a). These three groups were also distinguished on the Ward's cluster (Figure 8b). According to the datasets, the pooling of both carbonate crust microhabitats seemed to be due to their low number of individuals $(n=18$ and 53) rather than to the presence of shared taxa (Tables $3 a, b)$. When regarding the similarity level defined by the dotted line, the Ward's cluster also showed that the reduced sediments from Cheops had higher similarities with the carbonate crust microhabitats than with the other reduced sediment "soft" microhabitats (Figure 8b).

A PCA with Hellinger-transformed meiofaunal $>250 \mu \mathrm{m}$ data only (not shown) exhibited the same general distance patterns as the one with macrofauna sensu stricto (Procruste test stat $=0.53, p=0.013,1000$ permutations). However, meiofaunal 
sampling was very incomplete, especially on hard substratum, and these results might reflect this paucity of observations.
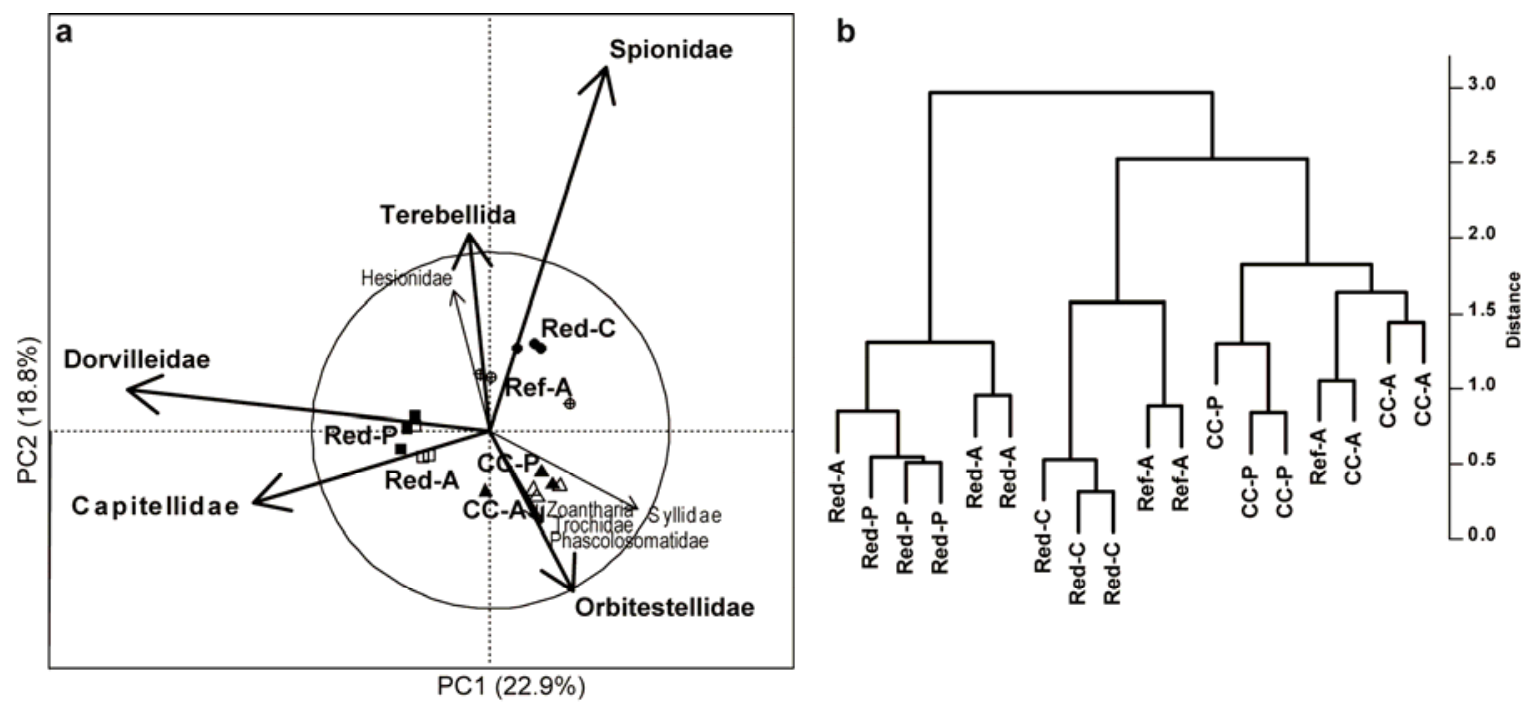

Fig. 8 (a) Principal Component Analysis (PCA, scaling type 1) of Hellinger-transformed macrofaunal abundances on the Amon MV (A), Pockmark area (P) and the Cheops MV (C). The first two axes represent $41.7 \%$ of the total variance in macrofaunal abundance. The circle of equilibrium indicates the significant contribution of five taxa (radius $=0.65$ ). Vectors shorter than 0.34 were removed. (b) Ward's hierarchical clustering was performed with Hellinger-transformed macrofaunal abundances for each microhabitat types. Red: reduced sediments, CC: carbonate crusts, and Ref: reference sample

\section{Discussion}

This study investigated the differences in faunal diversity in relation to different habitats and their biogeochemical conditions at three cold seep sites of the NDSF. Due to inevitably limited submersible time, sampling effort was relatively low given the high heterogeneity of cold seeps sites. Nevertheless, our results provide the first insights on seep faunal composition and diversity and their relationships with environmental conditions in the NDSF area.

\subsection{Difference between the reference site and cold seep habitats at Amon MV}

The reference site did not show any evidence of seepage whether direct (i.e. no detection of methane and sulphide fluxes) or indirect (i.e. absence of symbiontbearing fauna). The fauna found at the reference site was different from that of the reduced habitats and carbonate crusts from Amon. Densities of macro- and meiofauna were two-fold lower than in reduced sediments, and total benthic oxygen 
consumption was an order of magnitude lower. Accordingly, biomass was 1-4 orders of magnitude lower than at all other active sites from Amon. The reference site showed a relatively high evenness, but a lower diversity than the reduced sediment sites of Amon, therefore refuting our initial hypothesis. The reduced sediment microhabitats sampled within the present study support an overall higher faunal diversity compared to close-by oxygenated habitats. This pattern has already been observed on Eel River at about $500 \mathrm{~m}$ depth where diversity on clam beds was similar or higher than on non-seep sites (Levin et al. 2003; Levin et al. 2010). However, this is in contradiction with other studies from 770 to $3200 \mathrm{~m}$ depth were diversity appears to be lower at active seep sites (Sahling et al. 2002; Levin et al. 2010; Menot et al. 2010)

Comparing among sites, the relationship between seepage activity and diversity could best explained by a hump-shaped curve. We suggest that at the relatively low sulphide concentrations encountered at Amon the reduced sediments could be considered as an "ecotone" enhancing diversity by presenting a high variability of chemical environment and ecological niches, favoring the establishment of symbiontbearing fauna but not limiting heterotrophic fauna by toxic concentrations of sulphide (Cordes et al. 2010). In contrast, the Pockmark area or similarily active seeps such as Hydrate ridge (Sahling et al. 2002) appear to show declined diversity, despite the high abundances/biomasses observed, potentially selecting for specialists able to withstand high sulfide concentrations and fluxes.

\subsection{Reduced sediment microhabitats}

The reduced sediment microhabitats were influenced by fluid emissions as attested by biogeochemical conditions. Sulphide concentrations at $12 \mathrm{~cm}$ below the seafloor in the Pockmark area were 10 times higher than what was observed on Amon for the same sediment depth. This flux was associated with a higher oxygen uptake and faster consumption at the water-sediment interface, suggesting higher microbial activity within reduced sediments of the Pockmark area compared to all other sites. According to a previous study (Girnth et al. 2010), some evidences of brine overflowing the sediments were recorded at Amon reduced sediments. However, the homogeneity of the chloride profiles at both sites does not support the presence of upward seepage of saline fluids as observed in some areas of Cheops. 
Biogeochemical measurements indicate a ranking of activity with the Pockmark reduced sediments as the most sulphidic habitat, followed by Amon and Cheops.

Accordingly, the reduced sediment microhabitats at Amon and the Pockmark area were colonized by symbiont-bearing species, including siboglinid polychaetes and bivalves (Vesicomyidae, Lucinidae, Mytilidae and Thyasiridae) as well as by dorvilleid and capitellid polychaetes. The presence of these two families provides direct evidence for fluid emissions as they are usually associated with areas rich in organic matter and with sulphidic environments (Rouse and Fauchald 1997). Dorvilleid polychaetes also dominate reduced sediment microhabitats from other seep sites at $1100 \mathrm{~m}$ depth in the Marmara Sea (Ritt et al. 2010), at $2020 \mathrm{~m}$ depth in the Mediterranean Sea (Amsterdam MV, Ritt et al., in prep.) and at $500 \mathrm{~m}$ depth at the Eel River off California (Levin et al. 2003). Large nematodes were abundant in the reduced sediments of Amon, as previously observed on other mud volcanoes at 1220 (Van Gaever et al. 2006) and 5000 m depth (Olu et al. 1997).

The fauna in the reduced sediment microhabitat from Amon hosted the highest abundance of symbiont-bearing species, and its macrofaunal taxonomic richness was two times higher than in the Pockmark area. The bivalve species observed in the Pockmark area either harbored sulphide-oxidizing endosymbionts such as Lucinoma kazani and Isorropodon perplexum (Salas and Woodside 2002; Olu-Le Roy et al. 2004) or different types of symbionts as in the undetermined species Idas sp. Med, (Duperron et al. 2008).

On Cheops, the reduced sediments sampled were located about $250 \mathrm{~m}$ away from a brine lake which features extreme physico-chemical conditions. Methane concentrations at the surface of the lake varied from 2.4 to $3.7 \mathrm{mmol} \mathrm{I}^{-1}$ with temperatures of $20-40^{\circ} \mathrm{C}$ and salinities 210 to $244 \mathrm{~g} \mathrm{I}^{-1}$ (Mastalerz, Harmegnies, pers. com.). Sediment cores revealed a dark layer covering a layer of brown hemipelagic sediments, suggesting the occurrence of a relatively recent sulphidic mud flow. Sulfate reduction rates and oxygen consumption rates were considerably lower than at the other sites, indicating a low sulphide flux, as confirmed by pore water measurements. Accordingly, despite the detection of elevated methane concentrations in the bottom waters of Cheops above the reduced sediments, no 
symbiont-bearing fauna was observed. This microhabitat was dominated by spionid $\left(\sim 2200\right.$ individuals $\left.\mathrm{m}^{-2}\right)$ or terebellid $\left(\sim 660\right.$ individuals $\left.\mathrm{m}^{-2}\right)$ polychaetes, commonly found in sandy or muddy environments, from intertidal habitats to abyssal depths (Rouse and Pleijel 2001). Dense Terebellida beds, especially the Ampharetidae family have been observed at about $1100 \mathrm{~m}$ depth on the New Zealand margin (Sommer et al. 2009) and in the Marmara Sea (Ritt et al. 2010), as well as at $770 \mathrm{~m}$ at Hydrate Ridge off Oregon (Levin et al. 2010) where methane concentrations in the bottom water reach up to $2 \mathrm{mmol} \mathrm{I}^{-1}$ and $0.7 \mathrm{mmol}^{-1}$, respectively for the first two first. At Cheops, methane concentrations varied between 4 and $8 \mu$ mol $\mathrm{I}^{-1}$. This suggests that terebellids are able to inhabit a wide range of environmental conditions. Further chemical measurements are needed to have a better understanding of the intriguing processes occurring within reduced sediments on Cheops.

\subsection{Carbonate crust microhabitats}

As expected, the difference in substratum between the soft sediment and carbonate crust microhabitats appears to influence the composition and distribution of the seep fauna in the NDSF. Nevertheless, the clustering of the CC microhabitats from Amon and the Pockmark area appears to be due to the low number of sampled individuals rather than the presence of common taxa. Sampling efficiency on hard substrata does not appear to be ideal as suggested by the high heterogeneity between replicates and the low Jaccard's similarity coefficients obtained. However these results may reflect the real heterogeneity of this habitat in terms of faunal composition and spatial distribution. Visual observations showed that the carbonate crusts sampled in the Pockmark area were associated with reduced sediments whereas those from Amon did not appear to be located in the vicinity of an active area. In addition, the crusts showed different facies and colour that may reflect different fluid intensities and stages of evolution (Bayon et al. 2009a). For example, the carbonates from the south-western part of Amon are thick, dark and cemented, and can reach $1 \mathrm{~m}$ of thickness. They may have been formed in the distant past, during a period of intense fluid emissions (Dupré et al. 2007). The absence of symbiont-bearing fauna and the dark color of crusts - due to their exposure to oxygen-rich bottom water and their iron and manganese oxide cover - corroborate the hypothesis that these carbonates may be relatively old. Fluid emissions may be very low on this part of Amon, explaining the absence of symbiont-bearing fauna. The 
low faunal densities and biomass further support the fact that this environment is not favorable, neither to symbiont-bearing fauna, nor to heterotrophic fauna.

The light-colored and crumbly carbonates from the Pockmark area differed morphologically from the "inactive" crusts found on Amon as they seem to be relatively young. The precipitation of authigenic carbonates is controlled by high alkalinity of pore waters (Aloisi et al. 2002; Michaelis et al. 2002) due to the activity of consortia of archaea and bacteria involved in the anaerobic oxidation of methane (AOM) coupled to sulphate reduction (Boetius et al. 2000). Another by-product of AOM is sulphide which may support sulphide-oxidizing symbionts of chemosynthetic fauna such as the siboglinid polychaetes found beneath the crusts. In addition, the methane concentrations were high, reaching $>5 \mu \mathrm{mol} \mathrm{I}{ }^{-1}$. Siboglinids may contribute to bio-irrigation and favor advection and diffusion processes that play a significant role in carbonate precipitation (Bayon et al. 2009a).

\subsection{Comparison between Amon, the Pockmark area and Cheops}

The reduced sediment microhabitats appeared to be distributed along a gradient related to seepage intensity and thus, to methane, oxygen and sulphide fluxes; with the Pockmark area as the most intense seepage site. The fauna from the reduced sediment microhabitats of the Pockmark area and Amon were rather similar and highly influenced by the presence of symbiotic organisms as well as dorvilleid and capitellid polychaetes, usually associated with organically enriched, reduced environments (Rouse and Pleijel 2001). Both communities showed relatively similar oxygen consumption rates. The taxonomic diversity was higher on Amon followed by the Pockmark area and Cheops. However, the reduced sediments, associated with the debris-flow of the Pockmark area, were more sulphidic and probably also more stable than the fresh Amon mud flow. The lower diversity and biomass observed in the reduced sediments of the Pockmark could be due to the high level of sulphide flux limiting the survival of most benthic species.

At the time of sampling, the mud flow at Cheops was probably recent as only a very thin sulphidic horizon was observed on top of hemipelagic sediments. These conditions may explain the lower diversity and the lack of symbiont-bearing fauna on the sampling site located $250 \mathrm{~m}$ away from the central brine lake. According to video 
observations, instability seems to decrease from the summit toward the periphery as suggested by the presence of carbonate crusts with symbiont-bearing mytilids at about $700 \mathrm{~m}$ away from the lake.

\subsection{Comparison at a larger scale}

In terms of seepage activity, Amon is comparable to the Håkon Mosby MV (1200 m depth) from the Norwegian margin and the Amsterdam MV (2020 m depth) located on the Mediterranean Ridge. These MVs discharge mud, fluids and gases from their summits, which undergo episodic mud eruptions (Zitter et al. 2005; Dupré et al. 2007; Feseker et al. 2008). This activity induces instability and chemical gradients that influence the distribution of fauna, which is concentrically distributed around a chaotic summit (Zitter et al. 2005; Jerosch et al. 2007). The reduced site sampled at Amon was located on the base of the mud volcano, and influenced by lateral brine and mud flows (Girnth et al. 2011). Interestingly, the dimensions of the reduced sediment site was rather small (ca. $250 \mathrm{~m}$ ) and the next larger reduced sediment patches were $>2$ km away.

The carbonate crusts and reduced sediments of the Pockmark area from the NDSF showed similarities with a more recently discovered site, the giant REGAB pockmark in the Gulf of Guinea at $3160 \mathrm{~m}$ depth. There, carbonate crusts are colonized by dense mussel beds and siboglinid assemblages (Olu-Le Roy et al. 2007). Pockmark and carbonate crust areas have also been observed at $740 \mathrm{~m}$ depth on the Storegga slide and the Nyegga area located on the north-west of the Norway margin which have undergone slide events. There, benthic fauna is represented by Siboglinidae, Crinoidae, Pycnogonidae and microbial mats (Hovland et al. 2005; Hovland and Svensen 2006; Paull et al. 2008). However, these features are taller than those observed in the central province of the NDSF as they reach $190 \mathrm{~m}$ long and $40 \mathrm{~m}$ wide, while pockmarks do not exceed a few meters in diameter at the NDSF study site.

The Cheops MV share similarities with the Napoli MV located on the Mediterranean Ridge at $1900 \mathrm{~m}$ depth, as they both harbor brine seepages (Charlou et al. 2003). However, faunal density and taxonomic richness on Cheops are lower than those observed on Napoli (Ritt et al., in prep). Faunal composition and distribution may be 
strongly linked to the activity of the MV. Mud flows may initiate higher sedimentary and chemical instabilities on Cheops, limiting the colonization of benthic species. Although considered as an extreme habitat, the vicinity of brine lakes can be colonized by dense colonies of Porifera as observed on Napoli (Ritt, pers obs) or by dense mussel communities, such as those found on the shoreline of brine pools in the Gulf of Mexico at $650 \mathrm{~m}$ depth (Macdonald et al. 1990; Smith et al. 2000). The absence of dense assemblages of symbiont-bearing fauna close to the brines on Cheops was thus unexpected and may be explained by the effect of recent disturbances.

In conclusion, our comparative investigation of active cold seeps on the NDSF suggested that seepage activity substantially enhanced benthic activity, biomass and diversity compared to the surrounding oxygenated and oligotrophic deep-sea environments. The biomass and biogeochemical activity of seep associated communities is 1-2 orders of magnitude higher than the surrounding and diversity was increased by a factor of 1.5. Reduced sediment microhabitats exhibited highest biomasses and diversity in comparison with surrounding oxygenated areas (reference site). As expected, reduced sediments and carbonate crusts were characterized by distinct faunal composition and faunal similarities were observed within each microhabitat type regardless of the site and geological structure (i.e. mud volcano, pockmark). However, our heterogeneous results on carbonate crusts require more investigation and emphasize the importance of developing a specific sampling tool dedicated to hard substratum in the deep sea. No simple relationship was detected between chemical conditions, sediment instability, fluid intensity and community structure although there seems to be a gradient related to seepage intensity between the different sites (Pockmark>Amon>Cheops). Further investigations with an appropriate sampling strategy, especially regarding the meiofauna, may help in highlighting the links between faunal distribution and environmental conditions in the NDSF. Most likely, temporal dynamics in such active geological systems may be very important in structuring community diversity. It could be studied in the future by deploying autonomous video cameras and sensors as well as by regularly monitoring a same site. Time-series data would help determine the response of the fauna to instabilities and disturbances induced by the occurrence of 
mud flows or brine seepage, and in which ways local diversity is related to temporal fluctuations and stability of habitats.

\section{Acknowledgments}

The captains and crews of the R/V Meteor and R/V Pourquoi pas? as well as the pilots of the ROV Quest4000 and Victor6000 are warmly acknowledged for their dedicated assistance and for contributing to the success of the two cruises. The chief scientists of the two cruises were A Boetius (BIONIL, 2006) and C. Pierre (MEDECO leg 2). The faunal samples were identified by a network of taxonomists from the Muséum National d'Histoire Naturelle de Paris (France), the German Centre for Marine Biodiversity Research (Germany), the University of Lodz (Poland), the Russian Academy of Sciences of Moscow, the Kamchatka Branch of the Pacific Institute of Geography of Petropavlovsk-Kamchatsky and the Institute of Marine Biology of Vladivostok (Russia). Biogeochemical analyses were supported by Viola Beier, Tomas Wilkop, Janine Felden, Anna Lichtschlag, and Dirk de Beer (MPI for Marine Microbiology). The bathymetric maps were made with the data acquired and processed by Jean Mascle (Géosciences Azur) and Stéphanie Dupré (Ifremer). The first version of the manuscript was professionally edited by Carolyn Engel-Gautier. BR's thesis was entirely funded by the French Institute for the Exploitation of the Sea (Ifremer). This research project benefited from funds from the HERMES and HERMIONE European projects (contract \# 511234 and \#226354) as well as from the ANR DEEP-OASES (ANR06BDV005) and support from the GDR ECCHIS. Additional funds were available from the DFG (METEOR expedition M70-2), and from the Max Planck Society.

\section{References}

Aloisi G, Bouloubassi I, Heijs SK, Pancost RD, Pierre C, Sinninghe Damste JS, Gottschal JC, Forney LJ, Rouchy JM (2002) $\mathrm{CH}_{4}$-consuming microorganisms and the formation of carbonate crusts at cold seeps. Earth and Planetary Science Letters 203: 195-203

Baker MC, Ramirez-Llodra EZ, Tyler P, German CR, Boetius A, Cordes EE, Dubilier N, Fisher CR, Levin LA, Metaxas A, Rowden AA, Santos RS, Shank TM, Van Dover CL, Young CM, Warén A (2010) Biogeography, Ecology, and Vulnerability of Chemosynthetic Ecosystems in the Deep Sea. In: McIntyre A (ed) Life in the World's Oceans: Diversity, Distribution, and Abundance. WileyBlackwell, pp 384 
Bayon G, Henderson GM, Bohn M (2009a) U-Th stratigraphy of a cold seep carbonate crust. Chemical Geology 260: 47-56

Bayon G, Loncke L, dupre S, ducassou E, Duperron S, Etoubleau J, Foucher JP, Fouquet Y, Gontharet S, Huguen C, Klaucke I, Mascle J, Olu-Le Roy K, Ondreas H, Pierre C, Sibuet M, Stadnitskaia A, Woodside J (2009b) Multidiscinplinary investigations of fluid seepage on an unstable margin: The case of the Central Nile deep sea fan. Marine Geology 261: 92.104

Bellaiche G, Loncke L, Gaullier V, Mascle J, Courp T, Moreau A, Radan S, Sardou O (2001) The Nile Cone and its channel system: new results after the Fanil cruise. Comptes Rendus De L'Academie Des Sciences Série II Fascicule aSciences De La Terre Et Des Planètes 333: 399-404

Boetius A, Ravenschlag K, Schubert CJ, Rickert D, Widdel F, Gieseke A, Amann R, Jorgensen BB, Witte U, Pfannkuche O (2000) A marine microbial consortium apparently mediating anaerobic oxidation of methane. Nature 407: 623-626

Campbell KA (2006) Hydrocarbon seep and hydrothermal vent paleoenvironments and paleontology: Past developments and future research directions. Palaeogeography Palaeoclimatology Palaeoecology 232: 362-407

Charlou JL, Donval JP, Zitter T, Roy N, Jean-Baptiste P, Foucher JP, Woodside J (2003) Evidence of methane venting and geochemistry of brines on mud volcanoes of the eastern Mediterranean Sea. Deep Sea Research Part I: Oceanographic Research Papers 50: 941-958

Cita MB, Ryan WBF, Paggi L (1981) Prometheus mud breccia. An example of shale diapirism in the western Mediterranean Ridge. Ann. geol. Des Pays Hell. 13: 37-49

Cline JD, (1969) Spectrophotometric Determination of Hydrogen Sulfide in Natural Waters. Limnology and Oceanography 14: 454-458

Cordes EE, Becker EL, Hourdez S, Fisher CR (2010) Influence of foundation species, depth, and location on diversity and community composition at Gulf of Mexico lower-slope cold seeps. Deep Sea Research Part II: Topical Studies in Oceanography 57: 1870-1881

Dando PR, Austen MC, Burke RA, Kendall MA, Kennicutt MC, Judd AG, Moore DC, Ohara SCM, Schmaljohann R, Southward AJ (1991) Ecology of a North-Sea Pockmark with an active methane seep. Marine Ecology-Progress Series 70: 49-63

de Beer D, Sauter E, Niemann H, Kaul N, Foucher JP, Witte U, Schlüter M, Boetius A (2006) In situ fluxes and zonation of microbial activity in surface sediments of the Hâkon Mosby mud volcano. Limnology and Oceanography 51: 1315-1331

Dimitrov LI (2002) Mud volcanoes - the most important pathway for degassing deeply buried sediments. Earth-Science Reviews 59: 49-76

Duperron S, Halary S, Lorion J, Sibuet M, Gaill F (2008) Unexpected co-occurrence of six bacterial symbionts in the gills of the cold seep mussel Idas sp (Bivalvia : Mytilidae). Environmental Microbiology 10: 433-445

Dupré S, Buffet G, Mascle J, Foucher JP, Gauger S, Boetius A, Marfia C (2008) High-resolution mapping of large gas emitting mud volcanoes on the Egyptian continental margin (Nile Deep Sea Fan) by AUV surveys. Marine Geophysical Researches 29: 275-290

Dupré S, Woodside J, Foucher JP, de Lange G, Mascle J, Boetius A, Mastalerz V, Stadnitskaia A, Ondreas H, Huguen C, Harmegnies FO, Gontharet S, Loncke L, Deville E, Niemann H, Omoregie E, Roy KOL, Fiala-Medioni A, Dahlmann A, Caprais JC, Prinzhofer A, Sibuet M, Pierre C, Sinninghe Damste JS (2007) 
Seafloor geological studies above active gas chimneys off Egypt (Central nile deep sea fan). Deep-Sea Research Part I-Oceanographic Research Papers 54: $1146-1172$

Feseker T, Foucher JP, Harmegnies F (2008) Fluid flow or mud eruptions? Sediment temperature distributions on Håkon Mosby mud volcano, SW Barents Sea slope. Marine Geology 247: 194-207

Foucher JP, Westbrook GK, Boetius A, Ceramicola S, Dupre S, Mascle J, Mienert J, Pfannkuche O, Pierre C, Praeg D (2009) Structure and Drivers of Cold Seep Ecosystems. Oceanography 22: 92-109

Gauthier O, Sarrazin J, Desbruyères D (2010) Measure and mis-measure of species diversity in deep-sea chemosynthetic communities. Marine Ecology Progress Series 402: 285-302

Gini C (1912) Variabilità e Mutabilità. Tipographia di Paolo Cuppini, Bologna

Gontharet S, Pierre C, Blanc-Valleron MM, Rouchy JM, Fouquet Y, Bayon G, Foucher JP, Woodside J, Mascle J (2007) Nature and origin of diagenetic carbonate crusts and concretions from mud volcanoes and pockmarks of the Nile deep-sea fan (eastern Mediterranean Sea). Deep-Sea Research Part IITopical Studies In Oceanography 54: 1292-1311

Gotelli NJ, Colwell RK (2001) Quantifying biodiversity: procedures and pitfalls in the measurement and comparison of species richness. Ecology Letters 4: 379-391

Gray JS (2000) The measurement of marine species diversity, with an application to the benthic fauna of the Norwegian continental shelf. Journal Of Experimental Marine Biology And Ecology 250: 23-49

Girnth A-C, Grünke S, Lichtschlag A, Felden J, Knittel K, Wenzhöfer F, de Beer D, Boetius A (2011) A novel, mat-forming Thiomargarita population associated with a sulfidic fluid flow from a deep-sea mud volcano. Environmental Microbiology 13: 495-505

Grünke S, Felden J, Lichtschlag A, Girnth A-C, Wenzhöfer F, de Beer D, Boetius A (in press) Niche differentiation among mat-forming, sulfide-oxidizing bacteria at cold-seeps of the Nile Deep Sea Fan (Eastern Mediterranean Sea). Geobiology 9

Hessler RR, Jumars PA (1974) Abyssal community analysis from replicate box cores in the central North Pacific. Deep Sea Research 21: 185-209

Hill MO (1973) Diversity and Evenness: A unifying notation and its consequences. Ecology 54: 427-432

Hovland M, Gardner JV, Judd AG (2002) The significance of pockmarks to understanding fluid flow processes and geohazards. Geofluids 2: 127-136

Hovland M, Svensen H (2006) Submarine pingoes: Indicators of shallow gas hydrates in a pockmark at Nyegga, Norwegian Sea. Marine Geology 228: 1523

Hovland M, Svensen H, Forsberg CF, Johansen H, Fichler C, Fossa JH, Jonsson R, Rueslatten H (2005) Complex pockmarks with carbonate-ridges off midNorway: Products of sediment degassing. Marine Geology 218: 191-206

Hsu KJ, Montadert L, Bernoulli D, Cita MB, Erickson A, Garrison RE, Kidd RB, Melieres F, Muller C, Wright R (1977) History Of Mediterranean Salinity Crisis. Nature 267: 399-403

Huguen C, Foucher JP, Mascle J, Ondreas H, Thouement M, Stadnitskaia A, Pierre C, Bayon G, Loncke L, Boetius A, Bouloubassi I, De Lange G, Caprais JC, Fouquet $\mathrm{Y}$, Woodside J, Dupre S, and the NAUTINIL Scientific Party (2009) Menes Caldera, a highly active site of brine seepage in the Eastern 
Mediterranean Sea: "In situ" observations from the NAUTINIL expedition (2003) Marine Geology 261: 138-152

Huguen C, Mascle J, Woodside J, Zitter T, Foucher JP (2005) Mud volcanoes and mud domes of the Central Mediterranean Ridge: Near-bottom and in situ observations. Deep Sea Research Part I: Oceanographic Research Papers 52: 1911

Hurlbert SH (1971) The nonconcept of species diversity: A Critique and Alternative Parameters. Ecology 52: 577-586

Jaccard P (1901) Distribution de la flore alpine dans le Bassin des Dranses et dans quelques régions voisines. Bulletin de la société vaudoise des sciences naturelles

Jackson DA (1995) PORTEST: a PROcustean randomization TEST of community environment concordance. Ecosciences 2: 297-303

Jerosch K, Schluter M, Foucher JP, Allais AG, Klages M, Edy C (2007) Spatial distribution of mud flows, chemoautotrophic communities, and biogeochemical habitats at Hakon Mosby Mud Volcano. Marine Geology 243: 1-17

Jost G (2007) Partitioning diversity into independant alpha and beta components. Ecology 88: 2427-2439

Jost L (2006) Entropy and diversity. Oikos 113: 363-375

Judd AG, Hovland M (2007) Seabed fuid flow - The impact on geology, biology and the marine environment

Kindt R, Coe R (2005) Tree diversity analysis. A manual and software for common statistical methods for ecological and biodiversity studies. World Agroforestry Centre (ICRAF), Nairobi

Kopf AJ (2002) Significance of mud volcanism. Reviews of Geophysics 40: 52

Legendre P, Gallagher ED (2001) Ecologically meaningful transformations for ordination of species data. Oecologia 129: 271-280

Legendre P, Legendre L (1998) Numerical ecology, 2nd English ed.

Levin LA, Mendoza GF, Gonzalez JP, Thurber AR, Cordes EE (2010) Diversity of bathyal macrofauna on the northeastern Pacific margin: the influence of methane seeps and oxygen minimum zones. Marine Ecology 31: 94-110

Levin LA (2005) Ecology of cold seep sediments: Interactions of fauna with flow, chemistry and microbes Oceanography And Marine Biology - An Annual Review, Vol. 43. Crc Press-Taylor \& Francis Group, Boca Raton, pp 1-46

Levin LA, Mendoza GF (2007) Community structure and nutrition of deep methaneseep macrobenthos from the North Pacific (Aleutian) Margin and the Gulf of Mexico (Florida Escarpment). Marine Ecology-An Evolutionary Perspective 28: 131-151

Levin LA, Ziebis W, Mendoza GF, Growney VA, Tryon MD, Mahn C, Gieskes JM, Rathburn AE (2003) Spatial heterogeneity of macrofauna at northern California methane seeps: influence of sulfide concentration and fluid flow. MEPS 265: 123-139

Liu C, Whittaker RJ, Ma K, Malcolm JR (2007) Unifying and distinguishing diversity ordering methods for comparing communities. Population Ecology 49: 89-100

Loncke L, Mascle J, and the Fanil Scientific Party (2004) Mud volcanoes, gas chimneys, pockmarks and mounds in the Nile deep-sea fan (Eastern Mediterranean): geophysical evidences. Marine and Petroleum Geology 21: 669 
Macdonald IR, Reilly JF, Guinasso NL, Brooks JM, Carney RS, Bryant WA, Bright TJ (1990) Chemosynthetic mussels at a brine-filled pockmark in the Northern Gulf of Mexico. Science 248: 1096-1099

Mascle J, Sardou O, Loncke L, Migeon S, Camera L, Gaullier V (2006) Morphostructure of the Egyptian continental margin: Insights from swath bathymetry surveys. Marine Geophysical Researches 27: 49-59

Mascle J, Zitter T, Bellaiche G, Droz L, Gaullier V, Loncke L (2001) The Nile deep sea fan: preliminary results from a swath bathymetry survey. Marine and Petroleum Geology 18: 471-477

Menot L, Galéron J, Olu K, Caprais JC, Crassous P, Khripounoff A, Sibuet M (2010) Spatial heterogeneity of macrofaunal communities in and near a giant pockmark area in the deep Gulf of Guinea. Marine Ecology 31:78-93

Michaelis W, Seifert R, Nauhaus K, Treude T, Thiel V, Blumenberg M, Knittel K, Gieseke A, Peterknecht K, Pape T, Boetius A, Amann R, Jorgensen BB, Widdel F, Peckmann JR, Pimenov NV, Gulin MB (2002) Microbial reefs in the Black Sea fueled by anaerobic oxidation of methane. Science 297: 1013-1015

Milkov AV (2000) Worldwide distribution of submarine mud volcanoes and associated gas hydrates. Marine Geology 167: 29-42

Niemann H, Losekann T, de Beer D, Elvert M, Nadalig T, Knittel K, Amann R, Sauter EJ, Schluter M, Klages M, Foucher JP, Boetius A (2006) Novel microbial communities of the Haakon Mosby mud volcano and their role as a methane sink. Nature 443: 854-858

Oksanen J, Kindt R, Legendre P, O'Hara B, Simpson GL, Solymos P, Henry M, Stevens H, Wagner H (2008) Vegan: Community Ecology Package. R package version 1.15-1., pp http://cran.r-project.org/, http://vegan.r-forge.r-project.org/

Olu-Le Roy K, Caprais JC, Fifis A, Fabri MC, Galeron J, Budzinsky H, Le Menach K, Khripounoff A, Ondreas H, Sibuet M (2007) Cold-seep assemblages on a giant pockmark off West Africa: spatial patterns and environmental control. Marine Ecology-an Evolutionary Perspective 28: 115-130

Olu-Le Roy K, Sibuet M, Fiala-Medioni A, Gofas S, Salas C, Mariotti A, Foucher J-P, Woodside J (2004) Cold seep communities in the deep eastern Mediterranean Sea: composition, symbiosis and spatial distribution on mud volcanoes. Deep Sea Research Part I: Oceanographic Research Papers 51: 1915

Olu K, Lance S, Sibuet M, Henry P, Fiala-Medioni A, Dinet A (1997) Cold seep communities as indicators of fluid expulsion patterns through mud volcanoes seaward of the Barbados accretionary prism. Deep Sea Research Part I: Oceanographic Research Papers 44: 811

Omoregie EO, Mastalerz V, de Lange G, Straub KL, Kappler A, Roy H, Stadnitskaia A, Foucher JP, Boetius A (2008) Biogeochemistry and community composition of iron- and sulfur-precipitating microbial mats at the Chefren mud volcano (Nile Deep Sea fan, Eastern Mediterranean). Applied And Environmental Microbiology 74: 3198-3215

Patil GP, Taillie C (1982) Diversity as a Concept and its Measurement. Journal of the American Statistical Association 77: 548-561

Paull CK, Hecker B, Commeau R, Freeman-Lynde RP, Neumann C, Corso WP, Golubic S, Hook JE, Sikes E, Curray J (1984) Biological communities at the Florida Escarpment resemble hydrothermal vent taxa. Science 226: 965-967

Paull CK, Ussler W, Holbrook WS, Hill TM, Keaten R, Mienert J, Haflidason $\mathrm{H}$, Johnson JE, Winters WJ, Lorenson TD (2008) Origin of pockmarks and 
chimney structures on the flanks of the Storegga Slide, offshore Norway. GeoMarine Letters 28: 43-51

Pielou EC (1969) An introduction to mathematical ecology, New York

R Development Core Team (2009). R: A language and environment for statistical computing. R Foundation for Statistical Computing, Vienna, Austria

Ritt B, Desbruyeres D, Caprais JC, Khripounoff A, Le Gall C, Gauthier O, Buscail R, Olu K, Sarrazin J (in prep.) Cold seep communities in the deep eastern Mediterranean Sea: Composition, spatial patters and environmental control on the Mediterranean Ridge mud volcanoes

Ritt B, Sarrazin J, Caprais J-C, Noël P, Gauthier O, Pierre C, Henry P, Desbruyères D (2010) First insights into the structure and environmental setting of coldseep communities in the Marmara Sea. Deep Sea Research Part I: Oceanographic Research Papers 57: 1120-1136

Rouse GW, Fauchald K (1997) Cladistics and polychaetes. Zoologica Scripta 26: 139-204

Rouse GW, Pleijel F (2001) Polychaetes. Oxford University Press

Sahling H, Rickert D, Lee RW, Linke P, Suess E (2002) Macrofaunal community structure and sulfide flux at gas hydrate deposits from the Cascadia convergent margin, NE Pacific. Marine Ecology Progress Series 231:121-138

Salas C, Woodside J (2002) Lucinoma kazani n. sp. (Mollusca: Bivalvia): evidence of a living benthic community associated with a cold seep in the Eastern Mediterranean Sea. Deep Sea Research Part I: Oceanographic Research Papers 49: 991-1005

Sanders HL (1968) Marine benthic diversity: a comparative study. The American Naturalist 102: 243-282

Sarradin PM, Waeles M, Bernagout S, Le Gall C, Sarrazin J, Riso R (2009) Speciation of dissolved copper within an active hydrothermal edifice on the Lucky Strike vent field (MAR, $37^{\circ} \mathrm{N}$ ). Science of the Total Environment 407: 869-878

Sarradin PM, Caprais JC (1996) Analysis of dissolved gases by headspace sampling gas chromatography with column and detector switching. Preliminary results. Analytical Communications 33: 371-373

Sarrazin J, Juniper SK (1999) Biological characteristics of a hydrothermal edifice mosaic community. Marine Ecology-Progress Series 185: 1-19

Shannon CE (1948) A mathematical theory of communication. Bell System Technical Journal 27: 379-423

Sibuet M, Olu K (1998) Biogeography, biodiversity and fluid dependence of deep-sea cold-seep communities at active and passive margins. Deep Sea Research Part II: Topical Studies in Oceanography 45: 517

Simpson EH (1949) Measurement of diversity. Nature 163: 688

Smith EB, Scott KM, Nix ER, Korte C, Fisher CR (2000) Growth and condition of seep mussels (Bathymodiolus childressi) at a Gulf of Mexico Brine Pool. Ecology 81: 2392-2403

Sommer S, Linke P, Pfannkuche O, Niemann H, Treude T (2009) Benthic respiration in a seep habitat dominated by dense beds of ampharetid polychaetes at the Hikurangi Maring (new Zealand). Marine Geology doi: 10.1016/j.margo.2009.06.003

Southward EC, Andersen AC, Hourdez S (in press) Lamellibrachia anaximandri $\mathrm{n}$. sp., a new vestimentifera tubeworm from the Mediterranean (Annelida). Zoosystema 
Thistle D (2003) The deep-sea floor: an overview Ecosystems Of The Deep Ocean. Elsevier Science Bv, pp 5-37

Tothmérész B (1998) On the characterization of scale-dependant diversity. Abstracta Bonatica 22: 149-156

Treude T, Smith CR, Wenzhöfer F, Carney E, Bernardino AF, Hannides AK, Krüger M, Boetius A (2009) Biogeochemistry of a deep-sea whale-fall: sulfate reduction, sulfide efflux and methanogenesis. Marine Ecology Progess Series 382: 1-21

Van Gaever S, Moodley L, de Beer D, Vanreusel A (2006) Meiobenthos at the Arctic Håkon Mosby Mud Volcano, with a parental-caring nematode thriving in sulphide-rich sediments. Marine Ecology-Progress Series 321: 143-155

Werne JP, Haese RR, Zitter T, Aloisi G, Bouloubassi I, Heijs S, Fiala-Medioni A, Pancost RD, Sinninghe Damste JS, de Lange G (2004) Life at cold seeps: a synthesis of biogeochemical and ecological data from Kazan mud volcano, eastern Mediterranean Sea. Chemical Geology 205: 367

Whittaker RH (1960) Vegetation of the Siskiyou Mountains, Oregon and California. Ecological Monographs 30: 279

Zitter TAC, Huguen C, Woodside JM (2005) Geology of mud volcanoes in the eastern Mediterranean from combined sidescan sonar and submersible surveys. Deep-Sea Research Part I-Oceanographic Research Papers 52: 457475

Zitter TAC, Woodside JM, Mascle J (2003) The Anaximander Mountains: a clue to the tectonics of southwest Anatolia. Geological Journal 38: 375-394

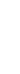


Table 1. Location, depth, and tools used to perform physico-chemical and faunal sampling at each microhabitat from the different sampling sites of the Nile Deep-Sea Fan explored during the BIONIL (2006) and MEDECO (2007) cruises. Sampling effort, length of each sediment cores and estimated surface of each piece of carbonate crusts are also reported. Further details of samples are archived in http://www.pangaea.de/PHP/CruiseReports.php?b=HERMES

\begin{tabular}{|c|c|c|c|c|c|}
\hline Microhabitat types & $\begin{array}{l}\text { Latitude } \\
\qquad\left({ }^{\circ} \mathrm{N}\right)\end{array}$ & $\begin{array}{l}\text { Longitude } \\
\left.\text { ( }{ }^{\circ} \mathrm{E}\right)\end{array}$ & $\begin{array}{l}\text { Depth } \\
\text { (m) }\end{array}$ & $\begin{array}{l}\text { Physico-chemical } \\
\text { measurements }\end{array}$ & Faunal sampling \\
\hline \multicolumn{6}{|c|}{ Reference site [ca. 15 km away from Amon MV (BIONIL, 2006)] } \\
\hline $\begin{array}{c}\text { Reference site } \\
\text { (Ref) }\end{array}$ & $32^{\circ} 21.42^{\prime}$ & $31^{\circ} 32.50^{\prime}$ & 1000 & $\begin{array}{c}3 \text { tubes (multicorer) } \\
\text { M70/2b_785 }\end{array}$ & $\begin{array}{c}3 \text { tubes }\left(74 \mathrm{~cm}^{2} \text { each }\right) \\
\text { Ref1 }(20 \mathrm{~cm}) \\
\text { Ref2 }(20 \mathrm{~cm}) \\
\text { Ref3 }(20 \mathrm{~cm})\end{array}$ \\
\hline \multicolumn{6}{|c|}{ Eastern Province - Amon MV (BIONIL, 2006) } \\
\hline $\begin{array}{l}\text { Reduced sediments } \\
\text { (Red) }\end{array}$ & $32^{\circ} 22.05^{\prime}$ & $31^{\circ} 42.27^{\prime}$ & 1154 & $\begin{array}{c}\text { Microsensor, chamber and } \\
\text { porewater samples } \\
\text { PC15, 46, } 47 \\
\text { M70/2b_765 (D115) } \\
\text { M70/2b_790 (D121) }\end{array}$ & $\begin{array}{c}3 \text { blade cores }\left(200 \mathrm{~cm}^{2} \mathrm{each}\right) \\
\text { Red1 (BCROV-2, } 10 \mathrm{~cm}) \\
\text { Red2 (BCROV-3, } 10 \mathrm{~cm}) \\
\text { Red3 (BCROV-8, } 10 \mathrm{~cm})\end{array}$ \\
\hline $\begin{array}{l}\text { Carbonate crusts } \\
\text { (CC) }\end{array}$ & $32^{\circ} 22.05^{\prime}$ & $31^{\circ} 42.27^{\prime}$ & 1153 & None & $\begin{array}{c}3 \text { pieces of crust } \\
\left.\text { CC1 (SFS-11, } 84 \mathrm{~cm}^{2}\right) \\
\left.\text { CC2 (SFS-111, } 103 \mathrm{~cm}^{2}\right) \\
\left.\text { CC3 (SFS-2, } 139 \mathrm{~cm}^{2}\right)\end{array}$ \\
\hline \multicolumn{6}{|c|}{ Central Province - Pockmark area, site 2A (BIONIL 2006) } \\
\hline $\begin{array}{l}\text { Reduced sediments } \\
\text { (Red) }\end{array}$ & $32^{\circ} 32.01^{\prime}$ & $30^{\circ} 21.13^{\prime}$ & 1697 & $\begin{array}{c}\text { Microsensor, chamber and } \\
\text { porewater samples } \\
\text { PC9, } 52 \\
\text { M70/2b_784 (D120) } \\
\text { M70/2b_841 (D127) }\end{array}$ & $\begin{array}{c}3 \text { blade cores }\left(200 \mathrm{~cm}^{2} \text { each) }\right. \\
\text { Red1 (BCROV-3, } 20 \mathrm{~cm}) \\
\text { Red2 (BCROV-7, } 17 \mathrm{~cm}) \\
\text { Red3 (BCROV-8, } 20 \mathrm{~cm})\end{array}$ \\
\hline $\begin{array}{l}\text { Carbonate crusts } \\
\text { (CC) }\end{array}$ & $32^{\circ} 32.00^{\prime}$ & $30^{\circ} 21.18^{\prime}$ & 1696 & None & $\begin{array}{c}3 \text { pieces of crust } \\
\text { CC1 (SFS-5, } 48 \mathrm{~cm}^{2} \text { ) } \\
\text { CC2 (SFS-7, } 81 \mathrm{~cm}^{2} \text { ) } \\
\text { CC3 (SFS-8, } 34 \mathrm{~cm}^{2} \text { ) }\end{array}$ \\
\hline \multicolumn{6}{|c|}{ Western Province - Cheops MV (MEDECO, 2007) } \\
\hline $\begin{array}{l}\text { Reduced sediments } \\
\text { (Red) }\end{array}$ & $32^{\circ} 08.05^{\prime}$ & $28^{\circ} 09.67^{\prime}$ & 3007 & $\begin{array}{c}\text { 3x2 water samples: } \mathrm{CH}_{4} \\
\text { MEDECO2_D343-PEPITO A-1 } \\
\text { and PEPITO A-2, A-2, B-1, B- } \\
\text { 2, C-1 and C-2 }\end{array}$ & $\begin{array}{c}3 \text { blade cores }\left(200 \mathrm{~cm}^{2} \text { each }\right) \\
\text { Red1 }(\mathrm{BL}-2,20 \mathrm{~cm}) \\
\text { Red2 }(\mathrm{BL}-4,19 \mathrm{~cm}) \\
\text { Red3 }(\mathrm{BL}-6,17 \mathrm{~cm})\end{array}$ \\
\hline
\end{tabular}




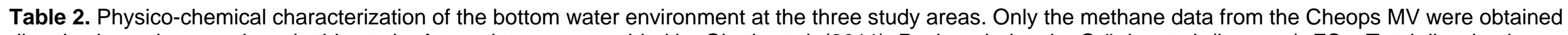
directly above the organisms in this study. Amon data were provided by Girnth et al. (2011), Pockmark data by Grünke et al. (in press). $\Sigma S=$ Total dissolved sulphides $\left(\mathrm{H}_{2} \mathrm{~S}+\mathrm{HS}^{-}+\mathrm{S}^{2-}\right), \mathrm{SR}=$ Sulphate reduction rate. The reference site was ca. $15 \mathrm{~km}$ away from the active centre of the Amon MV.

\begin{tabular}{|c|c|c|c|c|c|c|c|c|c|c|}
\hline & $\mathrm{pH}$ & $\begin{array}{c}{\left[\mathrm{O}_{2}\right]} \\
\text { Bottom } \\
\text { water } \\
\left(\mu \mathrm{mol} \mathrm{I}^{-1}\right)\end{array}$ & $\begin{array}{l}{\left[\mathrm{O}_{2}\right]} \\
\text { Penetration } \\
\text { depth } \\
(\mathrm{cm})\end{array}$ & $\begin{array}{l}\quad\left[\mathrm{O}_{2}\right] \\
\text { Total benthic } \\
\text { consumption } \\
\left(\mathrm{mmol} \mathrm{m}^{-2} \mathrm{~d}^{-1}\right)\end{array}$ & $\begin{array}{l}{\left[\mathrm{SO}_{4}{ }^{2-}\right]} \\
\text { Porewater } \\
\left(\mathrm{mmol} \mathrm{I}^{-1}\right)\end{array}$ & $\begin{array}{l}{[\mathrm{Cl}]} \\
\text { Porewater } \\
\left(\mathrm{mmol} \mathrm{I}^{-1}\right)\end{array}$ & $\begin{array}{c}{\left[\mathrm{CH}_{4}\right]} \\
\text { Bottom water } \\
\quad\left(\mu \mathrm{mol} \mathrm{I}^{-1}\right)\end{array}$ & $\begin{array}{l}{[\Sigma S]} \\
\text { Porewater } \\
\left(\mathrm{mmol} \mathrm{I}^{-1}\right)\end{array}$ & $\begin{array}{c}{[\Sigma S]} \\
\text { Porewater top } \\
5 \mathrm{~cm} / \text { peak conc. } \\
\left(\text { mmol l }{ }^{-1}\right)\end{array}$ & $\begin{array}{c}\text { SR } \\
\text { Sediments } \\
\left(\mathbf{m m o l ~ m}^{-2} \mathbf{d}^{-1}\right)\end{array}$ \\
\hline \multicolumn{11}{|l|}{ Amon MV } \\
\hline Reference site (Ref) & $8.20^{a}$ & $230^{\mathrm{a}}$ & $>4^{\mathrm{a}}$ & $<1^{a}$ & $31.4^{\mathrm{a}}$ & $529^{a}$ & $0.0^{\mathrm{a}}$ & $0^{\mathrm{a}}$ & - & $<0.2^{\mathrm{a}}$ \\
\hline Reduced sediments (Red) & $7.88^{b}$ & $150-200^{b}$ & $0.0-0.25^{b}$ & $10-46^{c}$ & $30.7-40.3^{d}$ & $404-580^{d}$ & $0.0^{d}$ & $<0.7^{\mathrm{b}}$ & $0.8 / 2.5^{d}$ & $0.5 \pm 0.2(n=3)^{d}$ \\
\hline \multicolumn{11}{|l|}{ Pockmark area } \\
\hline Reduced sediments (Red) & $8.11^{b}$ & $230^{\mathrm{e}}$ & $0.1-0.2^{b}$ & $156-174^{c}$ & $29.1-29.8^{d}$ & $606-630^{d}$ & $0.2-0.3^{e}$ & $\begin{array}{l}0.2^{b} \\
0.7^{d}\end{array}$ & $0.8 / 25^{d}$ & $22-41^{d}$ \\
\hline \multicolumn{11}{|l|}{ Cheops MV } \\
\hline Reduced sediments (Red) & - & $220^{\mathrm{e}}$ & - & $111-130^{c}$ & - & - & $3.60-9.34^{\dagger}$ & - & - & $5-14^{d}$ \\
\hline
\end{tabular}

Devices used to acquire the data: (a) multicorer, (b) microprofiler, (c) benthic chamber, (d) PCs, (e) KIPS bottle, (f) PEPITO, (-) no available data 
Table 3. AMON - Macrofaunal $\left(>250 \mu \mathrm{m}\right.$ ) densities (individuals $\mathrm{m}^{-2}$ ) per replicate and relative abundance (\%) of each taxa in the microhabitats studied on the Amon mud volcano: reduced sediments (Red, $n=3$ ), carbonate crusts $(\mathrm{CC}, \mathrm{n}=3)$ and the reference site (Ref, $\mathrm{n}=3)$. Total densities and relative abundances from each taxonomic group are highlighted in bold. Und. = undetermined individuals. ${ }^{*}$ ) Taxonomic level used for alpha-diversity analyses, here mostly family level. All sampling was performed during the BIONIL cruise (2006).

\begin{tabular}{|c|c|c|c|c|c|c|c|c|c|c|c|c|}
\hline \multirow[t]{2}{*}{ Taxonomic groups } & \multicolumn{4}{|c|}{ Reduced sediments } & \multicolumn{4}{|c|}{ Carbonate crusts } & \multicolumn{4}{|c|}{ Reference samples } \\
\hline & Red1 & Red2 & Red3 & $\%$ & CC1 & CC2 & $\mathrm{CC} 3$ & $\%$ & Ref1 & Ref2 & Ref3 & $\%$ \\
\hline Cnidaria (Total) & 0 & 0 & 0 & 0 & 0 & 0 & 935 & 72.21 & 0 & 270 & 135 & 17.65 \\
\hline Anthozoa - Zoantharia* & 0 & 0 & 0 & 0 & 0 & 0 & 935 & 72.21 & 0 & 0 & 0 & 0 \\
\hline Medusozoa - Scyphozoa* & 0 & 0 & 0 & 0 & 0 & 0 & 0 & 0 & 0 & 270 & 135 & 17.65 \\
\hline Polychaeta (Total) & 1900 & 400 & 1650 & 82.29 & 119 & 0 & 144 & 16.67 & 541 & 405 & 676 & 70.59 \\
\hline Capitellidae* & 1100 & 100 & 50 & 26.04 & 0 & 0 & 0 & 0 & 0 & 0 & 0 & 0 \\
\hline Dorvilleidae* & 300 & 50 & 1250 & 33.33 & 0 & 0 & 0 & 0 & 135 & 135 & 0 & 11.76 \\
\hline Hesionidae* & 0 & 0 & 50 & 1.04 & 0 & 0 & 0 & 0 & 0 & 0 & 0 & 0 \\
\hline Paraonidae* & 0 & 0 & 0 & 0 & 0 & 0 & 0 & 0 & 135 & 0 & 0 & 5.88 \\
\hline Pholoidae* & 0 & 0 & 0 & 0 & 0 & 0 & 144 & 11.11 & 0 & 0 & 0 & 0 \\
\hline Phyllodocidae* & 100 & 0 & 0 & 2.08 & 0 & 0 & 0 & 0 & 0 & 0 & 0 & 0 \\
\hline Spionidae* & 100 & 0 & 50 & 3.13 & 0 & 0 & 0 & 0 & 135 & 135 & 405 & 29.41 \\
\hline Siboglinidae, Frenulata* & 300 & 50 & 200 & 11.46 & 0 & 0 & 0 & 0 & 0 & 0 & 0 & 0 \\
\hline Syllidae* & 0 & 0 & 0 & 0 & 119 & 0 & 0 & 5.56 & 0 & 0 & 270 & 11.76 \\
\hline Terebellida* & 0 & 150 & 50 & 4.17 & 0 & 0 & 0 & 0 & 135 & 135 & 0 & 11.76 \\
\hline Larvae & 0 & 50 & 0 & 1.04 & 0 & 0 & 0 & 0 & 0 & 0 & 0 & 0 \\
\hline Bivalvia (Total) & 100 & 150 & 300 & 11.46 & 0 & 0 & 0 & 0 & 0 & 0 & 0 & 0 \\
\hline \multicolumn{13}{|l|}{ Lucinidae* } \\
\hline Lucinoma kazani & 0 & 150 & 50 & 4.17 & 0 & 0 & 0 & 0 & 0 & 0 & 0 & 0 \\
\hline \multicolumn{13}{|l|}{ Mytilidae* } \\
\hline Idas modiolaeformis & 50 & 0 & 0 & 1.04 & 0 & 0 & 0 & 0 & 0 & 0 & 0 & 0 \\
\hline \multicolumn{13}{|l|}{ Thyasiridae* } \\
\hline Thyasira striata & 0 & 0 & 100 & 2.08 & 0 & 0 & 0 & 0 & 0 & 0 & 0 & 0 \\
\hline \multicolumn{13}{|l|}{ Vesicomyidae* } \\
\hline Isorropodon perplexum & 0 & 0 & 150 & 3.13 & 0 & 0 & 0 & 0 & 0 & 0 & 0 & 0 \\
\hline \multicolumn{13}{|l|}{ Sareptidae* } \\
\hline Und. Sareptidae & 50 & 0 & 0 & 1.04 & 0 & 0 & 0 & 0 & 0 & 0 & 0 & 0 \\
\hline Gastropoda (Total) & 0 & 50 & 0 & 1.04 & 0 & 0 & 72 & 5.56 & 0 & 0 & 0 & 0 \\
\hline \multicolumn{13}{|l|}{ Calliotropidae* } \\
\hline Putzeysia wiseri & 0 & 0 & 0 & 0 & 0 & 0 & 72 & 5.56 & 0 & 0 & 0 & 0 \\
\hline Und. Gastropoda* & 0 & 50 & 0 & 1.04 & 0 & 0 & 0 & 0 & 0 & 0 & 0 & 0 \\
\hline Sipuncula (Total) & 0 & 0 & 0 & 0 & 0 & 97 & 0 & 5.56 & 0 & 0 & 135 & 5.88 \\
\hline \multicolumn{13}{|l|}{ Phascolosomatidae* } \\
\hline Phascolosoma aff. granulatum & 0 & 0 & 0 & 0 & 0 & 97 & 0 & 5.56 & 0 & 0 & 0 & 0 \\
\hline \multicolumn{13}{|l|}{ Golfingiidae* } \\
\hline Nephasoma minutum & 0 & 0 & 0 & 0 & 0 & 0 & 0 & 0 & 0 & 0 & 135 & 5.88 \\
\hline Crustacea (Total) & 50 & 50 & 150 & 5.21 & 0 & 0 & 0 & 0 & 0 & 0 & 135 & 5.88 \\
\hline Decapoda-Thalassinidae* & 0 & 0 & 50 & 1.04 & 0 & 0 & 0 & 0 & 0 & 0 & 0 & 0 \\
\hline \multicolumn{13}{|l|}{ Cumacea- Nannastacidae* } \\
\hline Cumella pygmaea & 0 & 0 & 50 & 1.04 & 0 & 0 & 0 & 0 & 0 & 0 & 0 & 0 \\
\hline Isopoda* & 0 & 0 & 0 & 0 & 0 & 0 & 0 & 0 & 0 & 0 & 135 & 5.88 \\
\hline Leptostraca* & 50 & 0 & 0 & 1.04 & 0 & 0 & 0 & 0 & 0 & 0 & 0 & 0 \\
\hline
\end{tabular}




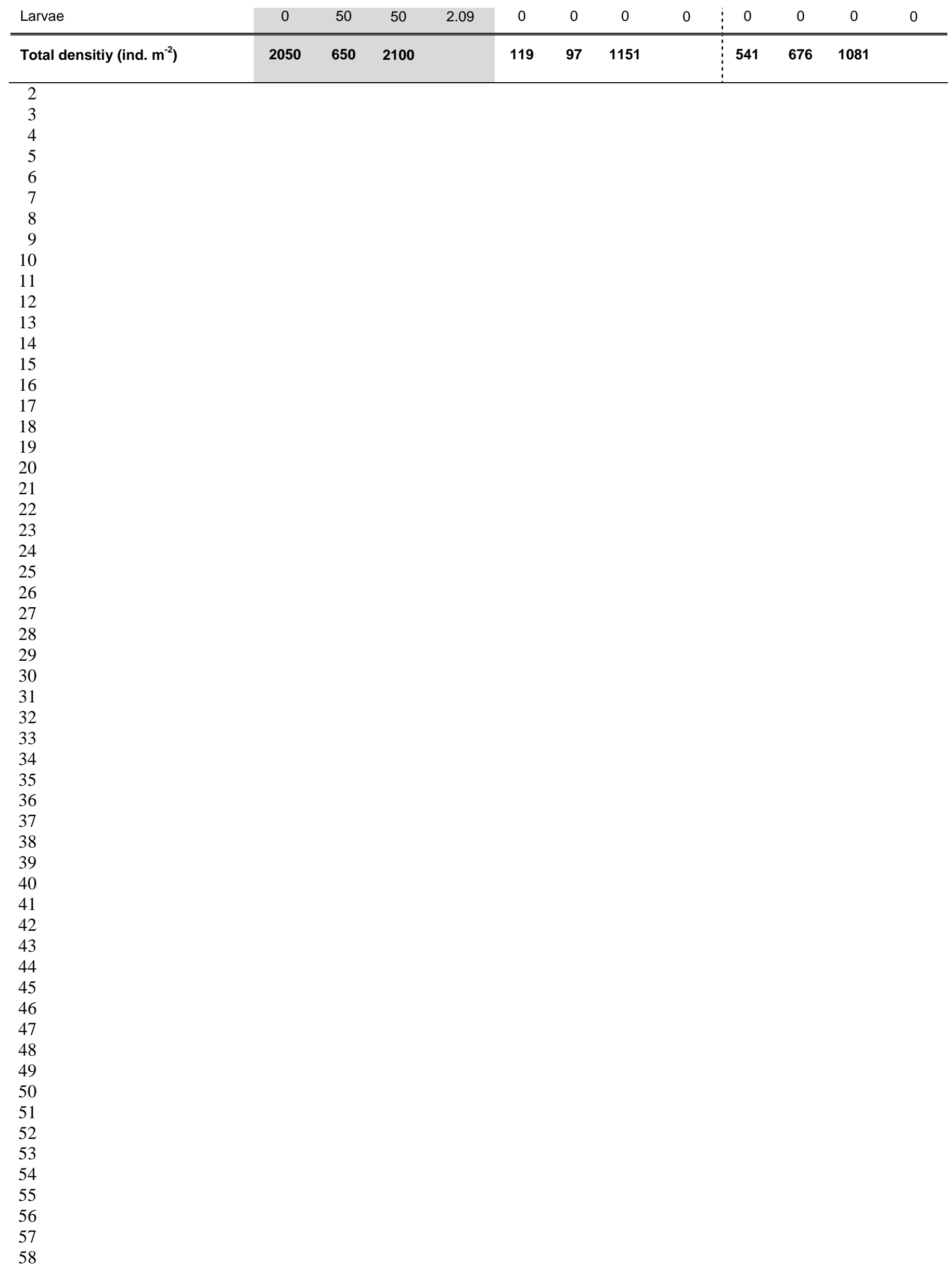


Table 4. POCKMARK area and CHEOPS - Macrofaunal $(>250 \mu \mathrm{m})$ densities (individuals $\mathrm{m}^{-2}$ ) per replicate and relative abundance (\%) of each taxa in the microhabitats studied in the Pockmark area: reduced sediments (Red, $n=3$ ), carbonate crusts $(C C, n=3)$ and on the Cheops MV: reduced sediments (Red, $n=3)$. Total densities and relative abundances from each taxonomic group are highlighted in bold. Und. = undetermined individuals. $\left({ }^{*}\right)$ Taxonomic level used for alpha-diversity analyses, here mostly family level. All sampling was performed during the BIONIL (2006) and MEDECO (2007) cruises.

\begin{tabular}{|c|c|c|c|c|c|c|c|c|c|c|c|c|}
\hline \multirow[t]{3}{*}{ Taxonomic groups } & \multicolumn{8}{|c|}{ Pockmark area } & \multirow{2}{*}{\multicolumn{4}{|c|}{$\begin{array}{c}\text { Cheops MV } \\
\text { Reduced sediments }\end{array}$}} \\
\hline & \multicolumn{4}{|c|}{ Reduced sediments } & \multicolumn{4}{|c|}{ Carbonate crusts } & & & & \\
\hline & Red1 & Red2 & Red3 & $\%$ & $\mathrm{CC1}$ & $\mathrm{CC2}$ & $\mathrm{CC} 3$ & $\%$ & Red1 & Red2 & Red3 & $\%$ \\
\hline Polychaeta (Total) & 2550 & 2650 & 1800 & 83.83 & 1042 & 123 & 4412 & 39.62 & 3800 & 5100 & 3000 & 95.58 \\
\hline Capitellidae* & 450 & 650 & 250 & 16.16 & 208 & 0 & 0 & 1.89 & 0 & 0 & 0 & 0 \\
\hline Cirratulidae* & 0 & 0 & 0 & 0 & 208 & 0 & 0 & 1.89 & 0 & 0 & 0 & 0 \\
\hline Dorvilleidae* & 1350 & 1500 & 1350 & 50.30 & 208 & 0 & 0 & 1.89 & 0 & 0 & 50 & 0.40 \\
\hline Glyceridae* & 50 & 0 & 0 & 0.60 & 0 & 0 & 0 & 0 & 0 & 0 & 0 & 0 \\
\hline Hesionidae* & 500 & 350 & 200 & 12.57 & 417 & 0 & 588 & 7.55 & 950 & 1050 & 1050 & 24.50 \\
\hline Sabellidae* & 0 & 0 & 0 & 0 & 0 & 0 & 2941 & 18.87 & 0 & 0 & 0 & 0 \\
\hline Spionidae* & 100 & 100 & 0 & 2.40 & 0 & 123 & 0 & 1.89 & 2750 & 2750 & 1300 & 54.62 \\
\hline Syllidae* & 0 & 0 & 0 & 0 & 0 & 0 & 294 & 1.89 & 0 & 0 & 0 & 0 \\
\hline Terebellida* & 100 & 50 & 0 & 1.80 & 0 & 0 & 588 & 3.77 & 100 & 1300 & 600 & 16.06 \\
\hline Bivalvia (Total) & 350 & 500 & 50 & 10.78 & 0 & 0 & 1176 & 7.55 & 0 & 0 & 0 & 0 \\
\hline \multicolumn{13}{|l|}{ Lucinidae* } \\
\hline Lucinoma kazani & 0 & 100 & 0 & 1.20 & 0 & 0 & 0 & 0 & 0 & 0 & 0 & 0 \\
\hline Und. Lucinidae & 0 & 100 & 0 & 1.20 & 0 & 0 & 0 & 0 & 0 & 0 & 0 & 0 \\
\hline \multicolumn{13}{|l|}{ Mytilidae* } \\
\hline Idas modiolaeformis & 0 & 0 & 0 & 0 & 0 & 0 & 1176 & 7.55 & 0 & 0 & 0 & 0 \\
\hline \multicolumn{13}{|l|}{ Vesicomyidae* } \\
\hline Isorropodon perplexum & 100 & 150 & 0 & 2.99 & 0 & 0 & 0 & 0 & 0 & 0 & 0 & 0 \\
\hline Und. Bivalvia & 150 & 150 & 50 & 5.39 & 0 & 0 & 0 & 0 & 0 & 0 & 0 & 0 \\
\hline Gastropoda (Total) & 0 & 350 & 100 & 5.39 & 1667 & 1728 & 1471 & 50.94 & 0 & 50 & 50 & 0.80 \\
\hline \multicolumn{13}{|l|}{ Calliotropidae* } \\
\hline Putzeysia wiseri & 0 & 0 & 0 & 0 & 208 & 123 & 294 & 5.66 & 0 & 0 & 0 & 0 \\
\hline Trochidae* & 0 & 0 & 0 & 0 & 208 & 123 & 588 & 7.54 & 0 & 0 & 0 & 0 \\
\hline \multicolumn{13}{|l|}{ Skeneidae* } \\
\hline Akritogyra conspicua & 0 & 0 & 0 & 0 & 0 & 123 & 0 & 1.9 & 0 & 0 & 0 & 0 \\
\hline Und. Skeneidae & 0 & 100 & 0 & 1.20 & 0 & 0 & 0 & 0 & 0 & 0 & 0 & 0 \\
\hline \multicolumn{13}{|l|}{ Orbitestellidae* } \\
\hline Lurifax vitreus & 0 & 0 & 0 & 0 & 1250 & 1358 & 588 & 35.85 & 0 & 0 & 0 & 0 \\
\hline Und. Gastropoda & 0 & 250 & 100 & 4.19 & 0 & 0 & 0 & 0 & 0 & 50 & 50 & 0.80 \\
\hline Crustacea (Total) & 0 & 0 & 0 & 0 & 0 & 0 & 294 & 1.89 & 200 & 100 & 150 & 3.61 \\
\hline \multicolumn{13}{|l|}{ Amphipoda-Gammaridae } \\
\hline \multicolumn{13}{|l|}{ Sebidae* } \\
\hline Seba sp. & 0 & 0 & 0 & 0 & 0 & 0 & 294 & 1.89 & 0 & 0 & 0 & 0 \\
\hline Und. Gammaridae & 0 & 0 & 0 & 0 & 0 & 0 & 0 & 0 & 50 & 0 & 0 & 0.40 \\
\hline \multicolumn{13}{|l|}{ Leptostraca } \\
\hline Nebaliidae* & 0 & 0 & 0 & 0 & 0 & 0 & 0 & 0 & 0 & 0 & 50 & 0.40 \\
\hline Und. Leptostraca & 0 & 0 & 0 & 0 & 0 & 0 & 0 & 0 & 150 & 100 & 100 & 2.81 \\
\hline Total density (ind. $\mathbf{m}^{-2}$ ) & 2900 & 3500 & 1950 & & 2708 & 1852 & 7353 & & 4000 & 5250 & 3200 & \\
\hline
\end{tabular}


Table 5. AMON - Meiofaunal $(>250 \mu \mathrm{m})$ densities (individuals $\mathrm{m}^{-2}$ ) per replicate and relative abundance (\%) of each taxa in the reduced sediment microhabitat (Red, $n=3$ ) studied on the Amon and in the reference samples (Ref, $n=3$ ). Total densities and relative abundances from each taxonomic group are highlighted in bold. Und. = undetermined individuals. $\left(^{*}\right)$ Taxonomic level used for alpha-diversity analyses, here mostly family level. All sampling was performed during the BIONIL cruise (2006).

\begin{tabular}{|c|c|c|c|c|c|c|c|c|c|c|c|c|}
\hline \multirow[t]{2}{*}{ Taxonomic groups } & \multicolumn{4}{|c|}{ Reduced sediments } & \multicolumn{4}{|c|}{ Carbonate crusts } & \multicolumn{4}{|c|}{ Reference site } \\
\hline & Red1 & Red2 & Red3 & $\%$ & CC1 & $\mathrm{CC2}$ & CC3 & $\%$ & Ref1 & Ref2 & Ref3 & $\%$ \\
\hline Nematoda (Total) & 74650 & 29900 & 28300 & 95.15 & 0 & 388 & 0 & 100 & 405 & 135 & 405 & 77.78 \\
\hline Crustacea (Total) & 900 & 1900 & 4000 & 4.85 & 0 & 0 & 0 & 0 & 270 & 0 & 0 & 22.22 \\
\hline \multicolumn{13}{|l|}{ Copepoda-Harpacticoida } \\
\hline \multicolumn{13}{|l|}{ Miraciidae* } \\
\hline Bulbamphiascus imus & 500 & 1050 & 200 & 1.24 & 0 & 0 & 0 & 0 & 0 & 0 & 0 & 0 \\
\hline Bulbamphiascus sp.1 & 0 & 0 & 0 & 0 & 0 & 0 & 0 & 0 & 0 & 0 & 0 & 0 \\
\hline Thyphlamphiascus confusus & 0 & 0 & 550 & 0.39 & 0 & 0 & 0 & 0 & 0 & 0 & 0 & 0 \\
\hline \multicolumn{13}{|l|}{ Ameiridae* } \\
\hline Amphiascus sp.2 & 0 & 0 & 0 & 0 & 0 & 0 & 0 & 0 & 0 & 0 & 0 & 0 \\
\hline Haifameira archibenthoica & 0 & 400 & 2400 & 2.00 & 0 & 0 & 0 & 0 & 0 & 0 & 0 & 0 \\
\hline Haifameira sp.1 & 0 & 0 & 200 & 0.14 & & & & & 0 & 0 & 0 & 0 \\
\hline \multicolumn{13}{|l|}{ Agestidae* $^{\star}$} \\
\hline Eurycletodes sp. & 0 & 0 & 0 & 0 & 0 & 0 & 0 & 0 & 270 & 0 & 0 & 22.22 \\
\hline \multicolumn{13}{|l|}{ Tisbidae* } \\
\hline Tisbella sp. & 0 & 0 & 0 & 0 & 0 & 0 & 0 & 0 & 0 & 0 & 0 & 0 \\
\hline Und. Harpacticoida & 0 & 0 & 50 & 0.07 & 0 & 0 & 0 & 0 & 0 & 0 & 0 & 0 \\
\hline \multicolumn{13}{|l|}{ Copepoda-Cyclopoida } \\
\hline \multicolumn{13}{|l|}{ Oncaeidae* } \\
\hline Oncaea sp. & 0 & 0 & 50 & 0.04 & 0 & 0 & 0 & 0 & 0 & 0 & 0 & 0 \\
\hline \multicolumn{13}{|l|}{ Copepoda-Calanoida* } \\
\hline Calanoida sp.1 & 0 & 150 & 450 & 0.43 & 0 & 0 & 0 & 0 & 0 & 0 & 0 & 0 \\
\hline Calanoida sp. & 0 & 300 & 0 & 0.21 & 0 & 0 & 0 & 0 & 0 & 0 & 0 & 0 \\
\hline Und. Calanoida & 300 & 0 & 0 & 0.21 & 0 & 0 & 0 & 0 & 0 & 0 & 0 & 0 \\
\hline \multicolumn{13}{|l|}{ Ostracoda } \\
\hline \multicolumn{13}{|l|}{ Polycopidae* } \\
\hline Polycope sp.3M & 50 & 0 & 0 & 0.04 & 0 & 0 & 0 & 0 & 0 & 0 & 0 & 0 \\
\hline \multicolumn{13}{|l|}{ Pontocyprididae* } \\
\hline Propontocypris sp.2M & 0 & 0 & 1 & 0.04 & 0 & 0 & 0 & 0 & 0 & 0 & 0 & 0 \\
\hline Propontocypris cf. levis & 50 & 0 & 0 & 0.04 & 0 & 0 & 0 & 0 & 0 & 0 & 0 & 0 \\
\hline$\%$ Meiofauna / Total fauna & 97.36 & 98.30 & 93.71 & & 0 & 80.00 & 0 & & 55.56 & 16.67 & 27.27 & \\
\hline Total density (ind. $\mathrm{m}^{-2}$ ) & 75500 & 31800 & 32300 & & 0 & 388 & 0 & & 676 & 135 & 405 & \\
\hline
\end{tabular}

61

62

63

64

65

66

67

68

69

70

71

72 
Table 6. POCKMARK area and CHEOPS - Meiofaunal $(>250 \mu \mathrm{m})$ densities (individuals $\mathrm{m}^{-2}$ ) per replicate and relative abundance (\%) of each taxa in the microhabitats studied on the Pockmark area: reduced sediments (Red, $n=3)$, carbonate crusts ( $C C, n=3$ ) and on the Cheops mud volcano (MV): reduced sediments (Red, $n=3$ ). Total densities and relative abundances from each taxonomic group are given in bold. Und. = undetermined individuals. (*) Taxonomic level used for alpha-diversity analyses, here mostly family level. All sampling was performed during the BIONIL (2006) and MEDECO (2007) cruises.

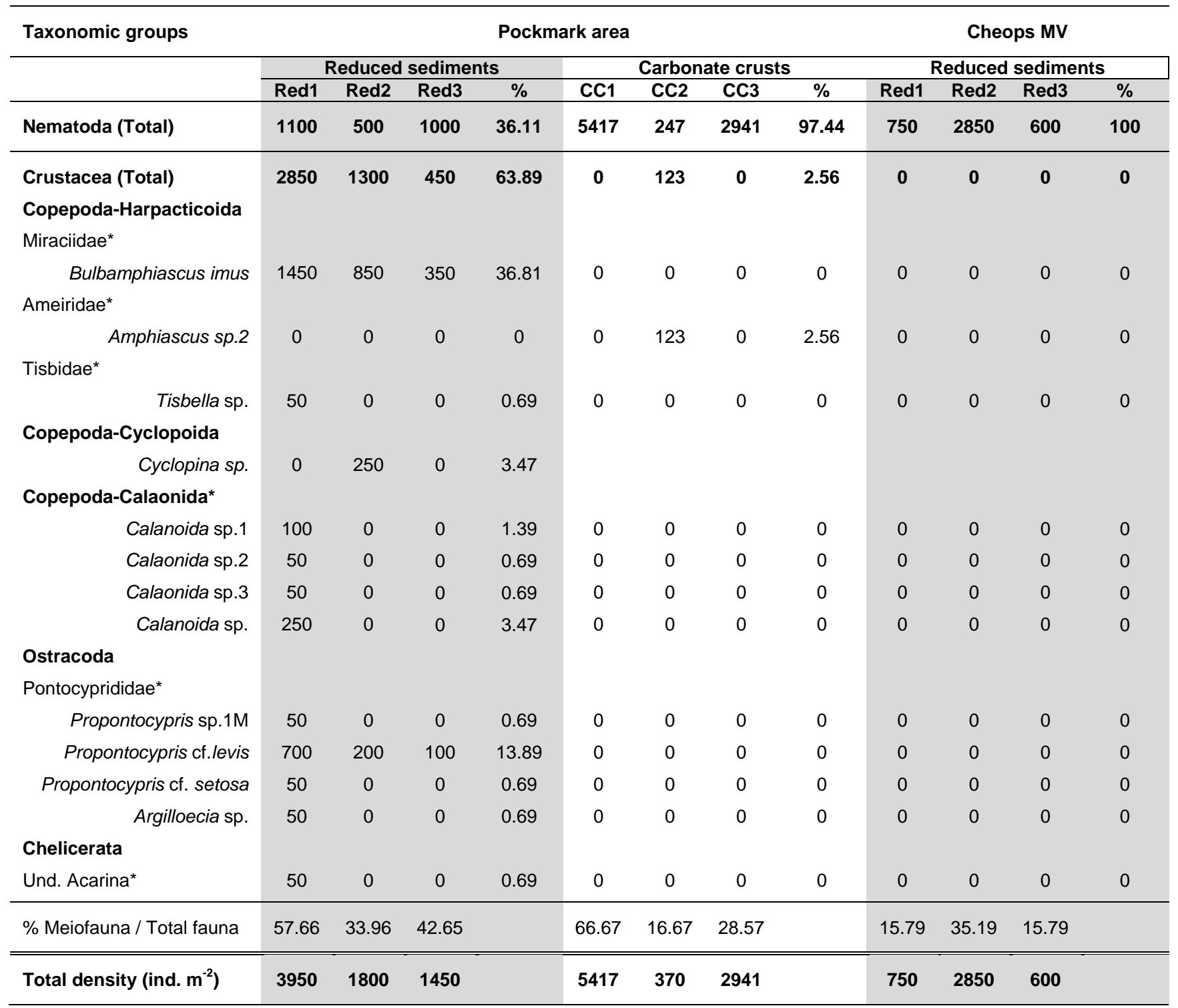

74 
Table 7. RED - Biological descriptors of the reduced sediment microhabitats sampled on the Amon MV, the Pockmark area and the Cheops MV in the Nile Deep-Sea Fan. The highest values are highlighted in bold. The meiofaunal data includes only the large meiofauna $>250 \mu \mathrm{m}$. The number equivalent of Shannon and Simpson indices are given in italics

\begin{tabular}{lccc}
\hline Biological descriptors & Amon & Pockmark area & Cheops \\
\hline Macrofauna -dominant & $\begin{array}{c}\text { Polychaetes reaching } \\
\begin{array}{l}8.3 \% \text { of total abundance } \\
\text { (Dorvilleidae, Capitellidae) }\end{array}\end{array}$ & $\begin{array}{c}\text { Polychaetes reaching 83.8\% } \\
\text { of total abundance } \\
\text { (Dorvilleidae) }\end{array}$ & $\begin{array}{c}\text { Polychaetes, reaching 95.6\% } \\
\text { of total abundance } \\
\text { (Spionidae, Hesionidae) }\end{array}$ \\
\hline Macrofauna -others & $\begin{array}{c}\text { Bivalves, crustaceans, } \\
\text { gastropods }\end{array}$ & Bivalves, gastropods & Crustaceans, gastropods \\
\hline $\begin{array}{l}\text { Mean macrofaunal densities } \\
\text { (individuals m }{ }^{-2} \text { ) }\end{array}$ & $1600 \pm 912$ & $2783 \pm 782$ & $\mathbf{4 1 5 0 \pm 1 0 3 3}$ \\
\hline Mean Jaccard's similarity & 0.32 & 0.47 & $\mathbf{0 . 7 7}$ \\
\hline $\begin{array}{l}\text { Symbiont-bearing fauna } \\
\text { Total macrofaunal biomass } \\
\text { (kg preserved wet weight } \mathrm{m}^{-2} \text { ) }\end{array}$ & $\mathbf{1 7 . 1 - 3 6 . 4 \%}$ & $0-10 \%$ & $0 \%$ \\
\hline
\end{tabular}

\section{Macrofaunal diversity indices}

\begin{tabular}{|c|c|c|c|}
\hline Total richness (S) & 15 & 9 & 6 \\
\hline $\begin{array}{l}\text { Shannon }\left(H_{e}^{\prime}\right) \\
\operatorname{Exp}\left(H_{e}^{\prime}\right)\end{array}$ & $\begin{array}{l}1.93 \\
6.89\end{array}$ & $\begin{array}{l}1.35 \\
3.86\end{array}$ & $\begin{array}{l}1.05 \\
2.86\end{array}$ \\
\hline $\begin{array}{l}\text { Gini-Simpson (DGS) } \\
\left(1 \text { / } 1-D_{G S}\right)\end{array}$ & $\begin{array}{l}0.78 \\
4.62\end{array}$ & $\begin{array}{l}0.63 \\
2.68\end{array}$ & $\begin{array}{l}0.59 \\
2.44\end{array}$ \\
\hline Evenness (J') & 0.71 & 0.61 & 0.59 \\
\hline Meiofauna $(>250 \mu \mathrm{m})$-dominant & $\begin{array}{l}\text { Nematodes with } 95.2 \% \text { of } \\
\text { the total abundance }\end{array}$ & $\begin{array}{c}\text { Copepods with } 63.9 \% \text { of the } \\
\text { total abundance }\end{array}$ & $100 \%$ nematodes \\
\hline Meiofauna $(>250 \mu \mathrm{m})$-others & Copepods, ostracods (6\%) & Acarina $(1.3 \%)$ & - \\
\hline $\begin{array}{l}\text { Mean meiofaunal densities } \\
\text { (individuals } \mathrm{m}^{-2} \text { ) }\end{array}$ & $46733 \pm 25004$ & $2400 \pm 1354$ & $1400 \pm 1258$ \\
\hline Mean Jaccard's similarity & 0.31 & 0.41 & 0.67 \\
\hline \multicolumn{4}{|l|}{ Meiofaunal diversity indices } \\
\hline Total richness (S)* & 7 & 7 & 1 \\
\hline Nematoda richmess & 1 & 1 & 1 \\
\hline Copepoda richness & 4 & 3 & 0 \\
\hline Ostracoda richness & 2 & 2 & 0 \\
\hline Acarina richness & 0 & 1 & 0 \\
\hline $\begin{array}{l}\text { Shannon }\left(H_{e}^{\prime}\right) \\
\operatorname{Exp}\left(H_{e}^{\prime}\right)\end{array}$ & $\begin{array}{l}0.24 \\
1.27\end{array}$ & $\begin{array}{l}1.39 \\
4.01\end{array}$ & 0 \\
\hline $\begin{array}{l}\left.\text { Gini-Simpson (D } \mathrm{D}_{\mathrm{GS}}\right) \\
\left(1 \text { / } 1-\mathrm{D}_{\mathrm{GS}}\right)\end{array}$ & $\begin{array}{l}0.09 \\
1.10\end{array}$ & $\begin{array}{l}0.70 \\
3.37\end{array}$ & - \\
\hline Evenness (J') & 0.12 & 0.71 & - \\
\hline
\end{tabular}


Table 8. $\mathrm{CC}$ and Ref - Biological descriptors of the carbonate crust microhabitats sampled on the Amon MV, in the Pockmark area and at the reference site (Amon MV) in the Nile Deep-Sea Fan. The highest values are highlighted in bold. The meiofauna data includes only the large meiofauna $>250 \mu \mathrm{m}$. The number equivalent of Shannon and Simpson indices are given in italics

\begin{tabular}{|c|c|c|c|}
\hline \multirow[t]{2}{*}{ Biological descriptors } & \multicolumn{2}{|c|}{ Carbonate crusts } & \multirow{2}{*}{$\begin{array}{l}\text { Reference site } \\
\text { Amon }\end{array}$} \\
\hline & Amon & Pockmark area & \\
\hline Macrofauna -dominant & $\begin{array}{l}\text { Cnidarians (Zoantharia) } \\
\text { reaching } 72.2 \% \text { of total } \\
\text { abundance }\end{array}$ & $\begin{array}{c}\text { Gastropoda (Lurifax vitreus) and } \\
\text { polychaetes (Sabellidae) in } \\
\text { various proportions, reaching } \\
50.9,39.6 \% \text { of total abundance }\end{array}$ & $\begin{array}{l}\text { Polychaetes, reaching a mean } \\
\text { of } 70.6 \% \text { of total abundance } \\
\text { (Spionidae) }\end{array}$ \\
\hline Macrofauna -others & $\begin{array}{l}\text { Gastropods, } \\
\text { sipunculians }\end{array}$ & Bivalves, crustaceans & $\begin{array}{c}\text { Cnidarians, sipunculians, } \\
\text { crustaceans }\end{array}$ \\
\hline $\begin{array}{l}\text { Mean macrofaunal densities } \\
\text { (individuals } \mathrm{m}^{-2} \text { ) }\end{array}$ & $456 \pm 602$ & $3971 \pm 2960$ & $766 \pm 281$ \\
\hline Mean Jaccard's similarity & 0.0 & 0.31 & 0.34 \\
\hline Symbiont-bearing fauna & $0 \%$ & $0-16 \%$ & $0 \%$ \\
\hline $\begin{array}{l}\text { Total macrofaunal biomass } \\
\text { (kg preserved wet weight } \mathrm{m}^{-2} \text { ) }\end{array}$ & $1.8^{\star} 10^{-3} \pm 5^{\star} 10^{-2}$ & $3^{\star} 10^{-2} \pm 5^{\star} 10^{-2}$ & $3.2^{*} 10^{-5} \pm 6^{*} 10^{-5}$ \\
\hline
\end{tabular}

\section{Macrofaunal diversity indexes}

\begin{tabular}{|c|c|c|c|}
\hline Total richness (S) & 5 & 14 & 8 \\
\hline Shannon $\left(\mathrm{H}_{\mathrm{e}}{ }^{\prime}\right)$ & 0.96 & 2.08 & 1.92 \\
\hline $\operatorname{Exp}\left(H_{e}^{\prime}\right)$ & 2.61 & 8.00 & 6.82 \\
\hline Gini-Simpson $\left(D_{G S}=1-\lambda\right)$ & 0.46 & 0.81 & 0.83 \\
\hline$(1 / \lambda)$ & 1.84 & 5.31 & 5.90 \\
\hline Evenness (J') & 0.60 & 0.79 & 0.92 \\
\hline Meiofauna $(>250 \mu m)$-dominant & $\begin{array}{l}\text { Only } 4 \text { individuals } \\
\text { (nematodes) }\end{array}$ & $\begin{array}{l}\text { Nematodes with } 97.4 \% \text { of the } \\
\text { total abundance }\end{array}$ & $\begin{array}{l}\text { Only } 9 \text { individuals (nematodes, } \\
\text { copepods) }\end{array}$ \\
\hline Meiofauna $(>250 \mu \mathrm{m})$-others & - & Copepods (11\%) & - \\
\hline Mean Jaccard's similarity & - & 0.67 & - \\
\hline \multicolumn{4}{|l|}{ Meiofaunal diversity indexes } \\
\hline Total richness $(\mathrm{S})^{\star}$ & 1 & 2 & 2 \\
\hline Nematoda richness & 1 & 1 & 1 \\
\hline Copepoda richness & 0 & 1 & 1 \\
\hline Ostracoda richness & 0 & 0 & 0 \\
\hline $\begin{array}{l}\text { Shannon }\left(\mathrm{H}_{\mathrm{e}}{ }^{\prime}\right) \\
\operatorname{Exp}\left(H_{e}^{\prime}\right)\end{array}$ & - & $\begin{array}{l}0.12 \\
1.13\end{array}$ & - \\
\hline $\begin{array}{l}\text { Gini-Simpson }\left(D_{G S}=1-\lambda\right) \\
(1 / \lambda)\end{array}$ & - & $\begin{array}{l}0.05 \\
1.05\end{array}$ & - \\
\hline
\end{tabular}


Evenness (J')

91

92

93

94

95 